\title{
The study on the preparation and characterization of gene-loaded immunomagnetic albumin nanospheres and their anti-cell proliferative effect combined with magnetic fluid hyperthermia on GLC-82 cells
}

This article was published in the following Dove Press journal:

Drug Design, Development and Therapy

15 December 2015

Number of times this article has been viewed

Hao Zhang,' Xinxin Hou, ${ }^{2}$ Mei Lin, ${ }^{3}$ Ling Wang,' Hongbo $\mathrm{Li}^{4}{ }^{4}$ Chenyan Yuan,' Chen Liang,' Jia Zhang, ${ }^{5}$ Dongsheng Zhang ${ }^{1,6}$

'Medical School of Southeast University, Nanjing, Jiangsu, People's Republic of China; ${ }^{2}$ Medical School of Henan Polytechnic University, Jiaozuo, Henan, People's Republic of China; ${ }^{3}$ Taizhou People's Hospital Affiliated to Nantong University, Taizhou, Jiangsu, People's Republic of China; ${ }^{4}$ Department of Ultrasound in Medicine, The First Affiliated Hospital (Jiangsu Province Hospital of TCM), Nanjing University of Chinese Medicine, Nanjing, Jiangsu, People's Republic of China; ${ }^{5}$ jiangsu Cancer Hospital, Nanjing, Jiangsu, People's Republic of China; ${ }^{6}$ Jiangsu Key Laboratory For Biomaterials and Devices, Nanjing, Jiangsu, People's Republic of China

\begin{abstract}
As one of the most common malignant tumors, the clinical and socio-economic consequences of lung cancer are significant. Currently, surgery is the main treatment strategy for this disease, but the survival rates of lung cancer patients are not ideal due to the high recurrence rate of the disease. Therefore, many researchers are exploring new specific therapeutic methods that are highly curative and minimally cytotoxic to healthy tissues. To this end, albumin nanospheres simultaneously were loaded with super-paramagnetic iron oxide nanoparticles (as gene vector and anticancer gene), and plasmid pDONR223-IFNG, and modified with anti-EGFR monoclonal antibody cetuximab as therapy. Targeting agents, namely gene-loaded immunomagnetic albumin nanospheres (cetuximab [C225]-IFNG-IMANS), were prepared for targeted lung carcinoma cells (GLC-82 cell lines). Transmission electron microscopy images showed that the C225-IFNG-IMANS were successfully prepared, and the ability of the nanospheres to target GLC-82 cells in vitro was confirmed by Prussian blue staining, immunofluorescence experiments, and magnetic resonance imaging. Transfection photographs and agarose gel electrophoresis proved that pDONR223-IFNG could be encased in the albumin nanospheres. A Cell Counting Kit-8 assay showed that the combination therapy group had significantly more therapeutic effects on GLC-82 cells than other therapy groups. A flow cytometry assay showed that the apoptotic index of the combined treatment group was $67.68 \%$, whereas the indices of the $\mathrm{C} 225$ group, gene therapy group, and magnetic fluid hyperthermia group were $12.2 \%, 16.34 \%$, and $20.04 \%$ respectively. Therefore, the combination of thermal treatment, molecular targeted treatment, and gene treatment synergistically targets GLC-82 cells, and the use of C225-IFNG-IMANS as a gene or drug carrier offers a novel and promising approach for the treatment of lung cancer.
\end{abstract}

Keywords: targeting gene therapy, nano-drug, magnetic nanoparticles

\section{Introduction}

Lung cancer is the most common malignant tumor of the respiratory system. Reports from the World Health Organization (WHO) indicate that the incidence of lung cancer ranks first among various types of malignant tumors. The main treatment strategies for lung cancer, including radiotherapy, chemotherapy, surgery, and biological therapy, have achieved certain curative effects, ${ }^{1}$ however, the survival rate for lung cancer patients remains low. Therefore, identifying a new method or combination of different methods that have mild side effects and accurately target lung cancer have
Correspondence: Dongsheng Zhang Medical School of Southeast University, No 87 Dingjiaqiao Road, Nanjing, 210009 , Jiangsu Province, People's Republic of China

Email zdszds1222@I63.com 
attracted the attention of researchers. In this study, the novel treatment method of combining gene therapy with thermotherapy and monoclonal antibody therapy was used to treat lung cancer in vitro.

In recent years, many new gene therapy methods (including immune gene therapy, suicide gene, RNA interference, etc) for tumor treatment have been researched. In the immune gene therapy, IFN $\gamma$, IL-2, and TNF $\alpha$ have been applied widely and have a more definite curative effect. The local expression of these genes in tumors can improve the immunogenicity of the tumor, and stimulate and enhance the body's anti-tumor immune responses. After the tumor cells are killed, the initial trigger action is finished. Immune gene therapy, which can be combined with the body's immune response, has become an attractive new prospect for lung cancer gene therapy.

However, the problem of gene transfer must be solved to successfully implement comprehensive tumor gene therapy. A viral vector system is the most effective method of gene transfer. However, due to its limitations, such as a lack of an efficient and directional vector system, the problem of controlling genes inside the body and, especially the safety issue, its clinical use is strictly controlled. A non-viral vector system can avoid the significant safety risks, but its transfection efficiency is less than that of the viral vector system. Therefore, the bottleneck of gene transfection has become a pressing matter of gene therapy.

Encouragingly, recently developed nanotechnology has offered a new method for solving the problem of the gene transfer vector. ${ }^{2-6}$ Gene transfer vectors based on nanoparticles have attracted extensive attention ${ }^{7,8}$ due to their large surface area and low toxicity. ${ }^{9-13}$ The use of nano-vectors for gene transfer has many advantages compared with traditional carriers, including the possibility of repeated injections, the slow release of the genes to effectively extend response time, the ability to maintain an effective concentration of the products, and the potential to improve the transfection efficiency and bioavailability of the products. Magnetic nanoparticles (MNPs) of $\mathrm{Fe}_{3} \mathrm{O}_{4}$ are the most commonly employed MNPs. They have interesting properties including biocompatibility, non-immunogenicity, superparamagnetism, and so on. ${ }^{14}$ Moreover, $\mathrm{Fe}_{3} \mathrm{O}_{4} \mathrm{MNPs}$ can absorb energy from the high-frequency alternating magnetic field (AMF) and thus, are useful for therapies based on tumor hyperthermia. This treatment approach is referred to as magnetic fluid hyperthermia (MFH); it specifically targets tumors and is thus more effective for deeply situated tumors. ${ }^{15}$

Molecular targeted therapy (MTT) refers to a new therapy designed to interfere with a specific molecular target or signaling pathway that may play a key role in tumor growth or progression. MTT can inhibit cell proliferation and induce apoptosis by specifically interfering with the signaling pathways of tumor cells, which may constitute an effective treatment strategy for cancer. This approach can more effectively kill cancer cells and reduce the damage to normal tissues. In recent years, the use of MTT as a clinical cancer treatment has gradually increased and shown many advantages over traditional methods. EGFR is expressed in various malignant tumor cells of epidermis origin, such as non-small cell lung cancer (NSCLC), ${ }^{16}$ breast cancer, colorectal cancer, ${ }^{17}$ gastric cancer, and prostate cancer, etc. EGFR and its ligand can form a dimer to activate tyrosine kinase (TK) and promote tumor cells' proliferation. Researchers have shown that 40\%-50\% of NSCLC overexpress EGFR. EGFR-targeted therapies, such as gefitinib, erlotinib, cetuximab (C225), ${ }^{18}$ and EMD7200, have been widely employed to treat lung cancer.

The affinity of the EGFR monoclonal antibodies for EGFR is higher than that of natural EGFR ligands. This antibody can be used to specifically interrupt cell pathways mediated by EGFR. Healthy cells express much less EGFR than malignant tissue, ${ }^{19}$ so monoclonal antibodies' role in this type of normal cells are very small. Monoclonal antibodies competitively bine EGFR to inhibit the activation of TK and block the signal transduction pathways associated with tumor cell proliferation. As a result, cell proliferation is inhibited and apoptosis is induced. C225, which binds to the extracellular domain of human EGFR, is a chimeric human/mouse immunoglobulin G1 antibody, which is marketed as Erbitux. C225 has been shown to synergistically affect tumors when combined with other chemotherapy drugs. ${ }^{20,21}$ However, the effectiveness rates of most targeted drugs are approximately $10 \%$. Thus, combination therapy has become an important development direction.

In this study, we prepared the gene-loaded magnetic albumin nanospheres (MANS) and the gene-loaded immunomagnetic albumin nanospheres (IMANS), coupled with C225 monoclonal antibodies. We then evaluated the targeting effect of the gene-loaded IMANS and explored the effectiveness of the combination of this thermal treatment, molecularly targeted treatment, and gene treatment as a new combination therapy for GLC-82 cells.

\section{Materials and methods Main materials}

Agarose was purchased from Sigma-Aldrich Co. (St Louis, MO, USA); 1640 medium and fetal bovine serum were obtained from Gibco (Thermo Fisher Scientific, Waltham, MA, USA); Cell Counting Kit-8 (CCK8) was obtained from 
Dojindo (Kumamoto, Japan); plasmid pEGFP (Promega Corporation, Fitchburg, WI, USA) was synthesized by Genepharma (Shanghai, People's Republic of China); plasmid pDONR223-IFNG was obtained from Biotech Co. Ltd., Changsha Ying Run (People's Republic of China); the Annexin V-FITC Apoptosis Detection Kit I was purchased from BD Biosciences (San Jose, CA, USA); GLC-82 cells were provided by the Institute of Biochemistry and Cell Biology of the Shanghai Institute of Biological Sciences at the Chinese Academy of Sciences.

\section{Preparation and characterization of the nanosized $\mathrm{Fe}_{3} \mathrm{O}_{4}$ and polyetherimide (PEI) $-\mathrm{Fe}_{3} \mathrm{O}_{4}$}

$\mathrm{Fe}_{3} \mathrm{O}_{4}$ nanoparticles were prepared by chemical coprecipitation. The procedure steps were as follows.

The solutions of $\mathrm{FeCl}_{3} \cdot 6 \mathrm{H}_{2} \mathrm{O}(0.1 \mathrm{~mol} / \mathrm{L}, 100 \mathrm{~mL})$ and $\mathrm{FeCl}_{2} \cdot 4 \mathrm{H}_{2} \mathrm{O}(0.1 \mathrm{~mol} / \mathrm{L}, 60 \mathrm{~mL})$ were mixed together under nitrogen purging and stirring (the molar proportion of iron(II) and iron(III) was 0.6). Ammonia (1.5 mol/L) was then dropped into the mixture until its $\mathrm{pH}$ reached 9. The dark precipitate appeared in the mixed solution rapidly. The solution was stirred for another 30 minutes. After 30 minutes ripening at $90^{\circ} \mathrm{C}$, the dark precipitates were isolated using a permanent magnet and dried under a vacuum. They were then examined by transmission electron microscopy (TEM) (JEM-2100, High Resolution). The diameter and zeta potential of $\mathrm{Fe}_{3} \mathrm{O}_{4}$ were measured by a dynamic light scattering (DLS) instrument. The $\mathrm{Fe}_{3} \mathrm{O}_{4}$ nanoparticles were subsequently modified by PEI, which was referred to in a previously described method. ${ }^{22}$ The detailed steps are as follows.

First, some $\mathrm{Fe}_{3} \mathrm{O}_{4}$ nanoparticles were dissolved in deionized water to prepare a $4 \%$ magnetic fluid; the supernatant was discarded after ultrasonic dispersion and high-speed centrifugation. Second, the precipitate was resuspended in phosphate-buffered saline (PBS) and ultrasonically dispersed. Third, PEI was added and the mixture was blended in a shaker at a constant temperature for 24 hours. The magnetic particles were separated from the solution using a magnetic method and washed repeatedly with distilled water and methanol. MNPs were dried under a vacuum (namely $\mathrm{PEI}-\mathrm{Fe}_{3} \mathrm{O}_{4}$ ).

The shape of the PEI-Fe ${ }_{3} \mathrm{O}_{4}$ particles was observed by TEM, and the adsorption efficiency of PEI was demonstrated by Fourier transform infrared spectroscopy (560; Thermo Nicolet, Madison, WI, USA). The zeta potential of PEI-Fe ${ }_{3} \mathrm{O}_{4}$ was measured by a DLS instrument.
Assessment of the capability of PEI- $-\mathrm{Fe}_{3} \mathrm{O}_{4}$ nanoparticles to bind to plasmid

The concentration of plasmid DNA in each experimental group was $0.01 \mu \mathrm{g} / \mu \mathrm{L}$. The nanoparticles and pEGFP plasmid DNA were mixed at the ratios of 0:1, 10:1, 30:1, 50:1, and 100:1 (w/w), and then incubated for 30 minutes at room temperature (RT). The binding efficiency was measured by agarose gel electrophoresis $(1 \% \mathrm{w} / \mathrm{v}$ agar, voltage: $90 \mathrm{~V}$, time: 30 minutes). The samples were analyzed using the GeneScan Analysis software.

\section{Preparation and characteristics of gene- loaded IMANS}

\section{Gene-loaded MANS were prepared by the} desolvation-crosslinking method

The PEI- $\mathrm{Fe}_{3} \mathrm{O}_{4}$ MNPs and plasmid pDONR223-IFNG/ pEGFP suspension of the indicated mass ratios were incubated for 30 minutes, bovine serum albumin (BSA) (100 mg) was then added, and the mixture was stirred. The $\mathrm{pH}$ of the mixture was adjusted to 9; ethanol was dropped into the solution at a rate of $1 \mathrm{~mL} / \mathrm{min}$, followed by the slow addition of $50 \mu \mathrm{L}$ of $2.5 \%$ glutaraldehyde. After stirring for 24 hours at RT, the solution was washed three times and the organic solvent added during the preparation was removed by high-speed centrifugation to yield the gene-loaded MANS (IFNG-MANS/EGFP-MANS). ${ }^{23}$

Gene-loaded IMANS were prepared by using the heterobifunctional cross-linker $\mathrm{N}$-succinimidyl-3-(2pyridyldithio)propionate (SPDP) to couple nanospheres and cetuximab monoclonal antibody (C225)

The specific steps were as follows.

An adequate amount of $\mathrm{C} 225$ was dissolved in $0.01 \mathrm{M}$ PBS ( $\mathrm{pH}=7.4$ ), and $20 \mathrm{mM}$ SPDP. Ethanol was added to the solution at a molar ratio of 1:15. After 60 minutes, the mixture was dialyzed with acetate buffer at RT to remove excess SPDP. A sufficient amount of DL-dithiothreitol was added to the pyridyldithiopropionate-activated C225 (C225-PDP) solution obtained in the previous step, and the mixture was gently stirred for 30 minutes at RT. The reactant was then dialyzed with PBS to remove redundant DL-dithiothreitol and obtain a sulfhydryl-activated C225 solution (C225-PDP-SH).

Second, an appropriate amount of gene-loaded MANS was diluted with acetate buffer, and $50 \mu \mathrm{L}$ of $20 \mathrm{mM}$ SPDP ethanol solution was added while stirring to remove excess SPDP.

Third, the activated gene-loaded MANS and C225PDP-SH mixture was incubated and shaken at $4{ }^{\circ} \mathrm{C}$ for 15 hours. After washing several times by centrifugation, 
gene-loaded IMANS (C225-IFNG-IMANS/C225-EGFPIMANS) were obtained. TEM and DLS were used to characterize the nanospheres.

\section{Cell transfection experiment}

Prior to transfection, $4 \mu \mathrm{g}$ of pEGFP plasmid DNA and PEI$\mathrm{Fe}_{3} \mathrm{O}_{4}$ nanoparticles or C225-EGFP-IMANS were (the mass ratio of PEI-Fe $\mathrm{O}_{4}$ to DNA was 50:1) each diluted in $250 \mu \mathrm{L}$ of serum-free medium. After incubation at RT for 5 minutes, plasmid DNA was added to the PEI-Fe $\mathrm{O}_{4}$ nanoparticles or C225-EGFP-IMANS suspensions, and the complexes were incubated for 30 minutes. As a control, commercially available transfection reagents, such as Lipofectamine ${ }^{\mathrm{TM}}$ 2000 (Invitrogen; Thermo Fisher Scientific) were used in accordance with the manufacturer's instructions.

GLC-82 cells and HEK293 cells (control cell line) were seeded in six-well plates, at an initial density of $3 \times 10^{5}$ cells/well in $2 \mathrm{~mL}$ of growth medium. After incubation for 24 hours and the cells had reached $80 \%$ confluence, the medium was replaced with $1.5 \mathrm{~mL}$ serum-free media and $500 \mu \mathrm{L}$ of $\mathrm{PEI}-\mathrm{Fe}_{3} \mathrm{O}_{4} / \mathrm{pEGFP}$ or C225-EGFP-IMANS complexes, and the cells were then incubated for another 4 hours. The medium was replaced with fresh medium containing serum, and the cells were incubated for another 48 hours. The cells were then observed under inverted fluorescence microscopy (TE2000; Nikon Corporation, Tokyo, Japan). The cells were then collected and examined by a flow cytometry instrument to determine the transfection efficiency. All cell studies were approved by the ethics committee of Southeast University, Nanjing, People's Republic of China.

\section{Targeting evaluation of gene-loaded MANS in vitro}

GLC-82 cells were incubated with C225-targeting groups (C225-IFNG-IMANS), and non-C225-targeting groups (IFNG-MANS) for 24 hours. Prussian blue staining, immunofluorescence experiments, and magnetic resonance imaging (MRI) were used to observe the specific binding ability of the immune nanospheres with human lung adenocarcinoma cells in vitro. The HL7702 cell line does not express EGFR and was used as a control.

\section{Prussian blue staining}

Aliquots $(1 \mathrm{~mL})$ of GLC-82/HL 7702 cells $\left(3 \times 10^{5} / \mathrm{mL}\right)$ in complete 1640 medium supplemented with $10 \%$ fetal calf serum (Gibco) were seeded into 12-well plates and cultured at $37^{\circ} \mathrm{C}$ in $5 \% \mathrm{CO}_{2}$ for 24 hours. C225-IFNG-IMANS and IFNG-MANS were added to five wells each, and the cells were incubated for 24 hours. The cells were then washed with PBS and stained with Prussian blue to observe intracellular $\mathrm{Fe}_{3} \mathrm{O}_{4}$ nanoparticles. The combination of nanospheres and cells can be observed by light microscopy.

\section{Immunofluorescence experiments}

The C225-IFNG-IMANS (immuno-nanospheres) were dissolved in PBS buffer containing serum, and incubated with rabbit anti-mouse IgG labeled with Alexa Fluor 488 for 30 minutes $\left(4^{\circ} \mathrm{C}\right)$. The control group was the IFNG-MANS incubated with the IgG. The nanospheres labeled with Alexa Fluor 488 were then incubated with the lung cancer GLC-82 cell lines, which were fixed with cold acetone. After 24 hours, the incubated cells were washed three times with PBS, and the nucleus were stained with 4',6-diamidino-2-phenylindole. A fluorescence microscope was used to observe the combination of nanospheres and cells. HL7702 cells served as a control for the above groups.

\section{$M R I$ in vitro}

GLC-82/HL 7702 cells $\left(3 \times 10^{5} / \mathrm{mL}\right)$ in complete 1640 medium supplemented with $10 \%$ fetal calf serum were seeded into six-well plates at $37^{\circ} \mathrm{C}$ and cultured in $5 \% \mathrm{CO}_{2}$ for 24 hours. C225-IFNG-IMANS or IFNG-MANS were added to the cells, which were then incubated for 24 hours. The cells were digested with $0.25 \%$ trypsin and collected and then resuspended in Eppendorf (EP) tubes with $0.5 \mathrm{~mL}$ $1 \%$ agarose after centrifugation. An EP tube with agarose was used as a control. The EP tubes were scanned with 7.0 Tesla small animals MRI. The T2 values were measured in multi-slice, multi-echo-T2-map sequences. The specific parameters were as follows: $3.0 \mathrm{~cm}$ diameter body coil, $5 \times 5 \mathrm{~cm}$ field of view, $1 \mathrm{~mm}$ thick, $256 \times 256$ matrix, TR: 2,000 ms, and TE: $30 \mathrm{~ms}$.

\section{Heating test of $\mathrm{Fe}_{3} \mathrm{O}_{4}$ MNPs and C225- IFNG-IMANS}

Various doses of $\mathrm{Fe}_{3} \mathrm{O}_{4}$ nanoparticles were dispersed in $5 \mathrm{~mL}$ $0.9 \% \mathrm{NaCl}$, at $\mathrm{Fe}_{3} \mathrm{O}_{4}$ concentrations of $0.5,1.0,1.5,2.0,2.5$, and $3.0 \mathrm{mg} / \mathrm{mL}$, and $2 \mathrm{~mL}$ aliquots of magnetic fluids were added to flat-bottomed cuvettes. These cuvettes were placed at the center of the hyperthermia coil of high-frequency electromagnetic field (SP-04C, Shenzhen, People's Republic of China). The output frequency was $230 \mathrm{kHz}$ and the output current was $25 \mathrm{~A}$. The temperature was measured every 5 minutes during 1 hour of incubation.

C225- IFNG-IMANS containing different amounts of iron were tested according to the above steps. The concentrations 
of iron in the C225-IFNG-IMANS were $0.125,0.25,0.375$, $0.5,0.625,0.75,0.875$, and $1.0 \mathrm{mg} / \mathrm{mL}$.

\section{The therapeutic effects of C225- IFNG- IMANS combined with MFH on cultured lung carcinoma GLC-82 CCK8 assay}

GLC- 82 cells $\left(4 \times 10^{4}\right)$ were cultured in three 96 -well plates. After 24 hours incubation, the cells were subjected to eight different conditions: negative control group (1640 containing 10\% fetal calf serum), C225 group (C225 solution), gene therapy group (gene-loaded albumin nanospheres [ANS], IFNG-ANS), C225 targeted gene therapy group (C225-IFNG-IANS), MFH group (MANS), C225 targeted MFH group (C225-IMANS), gene therapy and MFH combination group (IFNG-MANS), C225 targeted gene therapy and MFH combination group (C225-IFNG-IMANS). After incubation for 24 hours, the 96-well plates of magnetic targeting and double targeting groups were placed on a 96-well strong magnet (Magneto FACTOR plate, Chemicell, Berlin, Germany). The 96-well culture plates of the MFH groups were placed on a high-frequency $\operatorname{AMF}(\mathrm{f}=230 \mathrm{kHz}, \mathrm{I}=30 \mathrm{~A})$ to be heated for 1 hour. All groups continued to be incubated for 24 hours, 48 hours, and 72 hours, and $10 \mu \mathrm{L}$ of CCK8 solution was then added to each well, and the cells were further incubated at $37^{\circ} \mathrm{C}$ for $1-4$ hours. The optical density (OD) was read at $450 \mathrm{~nm}$ using a spectrophotometer (Infinite 50, TECAN, Männedorf, Switzerland). The following formula was used to calculate the cell relative growth rate (RGR):

$$
\text { RGR }=\frac{\begin{array}{c}
\text { The experimental group OD }- \\
\text { The blank control group } \\
\text { The negative control group OD }- \\
\text { The blank control group }
\end{array}}{\text { The }} \text {. }
$$

\section{Flow cytometry assay}

The GLC-82 cells in logarithmic growth phase were adjusted to the suspension with $3 \times 10^{5}$ cells $/ \mathrm{mL}$. The cells were grouped and handled as described in the CCK 8 assay section. After incubation for 48 hours, the cells from all eight groups were collected and rinsed three times with cold PBS, and resuspended in $1 \times$ binding buffer at a concentration of $1 \times 10^{6}$ cells $/ \mathrm{mL}$. Subsequently, $100 \mu \mathrm{L}$ of the solution was transferred into eight $5 \mathrm{~mL}$ culture tubes, and $5 \mu \mathrm{L}$ of fluorescein isothiocyanate Annexin $\mathrm{V}$ and $5 \mu \mathrm{L}$ of propidium iodide (PI) was added to each tube. After gentle blending and incubation for 15 minutes at RT $\left(25^{\circ} \mathrm{C}\right)$ in the dark, $400 \mu \mathrm{L}$ of $1 \times$ binding buffer was added to each tube. The tubes were then analyzed by flow cytometry within 1 hour.

\section{Statistical analysis}

Values were indicated as mean \pm standard deviation. The data were analyzed with the SPSS 16.0 program. A $P$-value of $<0.05$ was considered to indicate significant differences.

\section{Results and discussion Preparation and characterization of the nanosized $\mathrm{Fe}_{3} \mathrm{O}_{4}$ and $\mathrm{PEI}-\mathrm{Fe}_{3} \mathrm{O}_{4}$}

Figure 1A shows the TEM photos of $\mathrm{Fe}_{3} \mathrm{O}_{4}$ nanoparticles. Under TEM, the $\mathrm{Fe}_{3} \mathrm{O}_{4}$ nanoparticles showed high electron density. Their diameter was approximately $20 \mathrm{~nm}$. From the DLS results, we determined that the hydrodynamic size of $\mathrm{Fe}_{3} \mathrm{O}_{4}$ was $64.87 \mathrm{~nm}$ and the polydispersity index was 0.152 (Figure 1B). A problem we found was that the size of MNPs detected by DLS was larger than that observed under TEM. The reason is that the DLS measurement shows the hydrodynamic size of the nanoparticles. MNP aggregation is very easy, so the hydrodynamic size of the MNPs is larger than their actual size.

MNPs have recently emerged as a fundamental tool for biomedical technology. ${ }^{24}$ These advanced nanomaterials are used in key areas of biomedicine due to advantages of their large-scale synthesis ${ }^{25}$ and complex surface functionalization, including drug/gene therapy, ${ }^{26}$ magnetic targeting, ${ }^{27}$ and diagnostic imaging (as contrast enhancers). ${ }^{28}$

However, $\mathrm{Fe}_{3} \mathrm{O}_{4}$ nanoparticles cannot directly carry plasmid and require surface modification to deliver plasmids to cells. The monomer (-CH-CH2-NH2-) PEI, a common powder surface modification agent, can bind to DNA and adhere to cells, and exerts electrostatic repulsion and steric hindrance effects. ${ }^{29-31} \mathrm{In}$ our previous study, $\mathrm{Mn}_{0.5} \mathrm{Zn}_{0.5} \mathrm{Fe}_{2} \mathrm{O}_{4}$ nanoparticles were successfully surface-modified by PEI, and used to transfect pEgr1-HSV-TK/GCV into cancer cells to treat hepatoma. ${ }^{32}$

In this study, we prepared $\mathrm{PEI}-\mathrm{Fe}_{3} \mathrm{O}_{4}$ nanoparticles whose shape and size were similar to those of $\mathrm{Fe}_{3} \mathrm{O}_{4}$ nanoparticles (Figure 2A). Fourier transform infrared spectroscopy indicated specific peaks at $3,043.6 \mathrm{~cm}^{-1}, 2,950.1 \mathrm{~cm}^{-1}$, $1,464.8 \mathrm{~cm}^{-1}$, which were due to the chemical structure of the PEI polymer coating on the MNPs (Figure 2B). The surface charge of $\mathrm{Fe}_{3} \mathrm{O}_{4}$ in $\mathrm{pH} 7$ was $0 \pm 0.5 \mathrm{mV}$ and turned into $36.3 \pm 0.6 \mathrm{mV}$ after being modified with PEI (Figure 2C). 


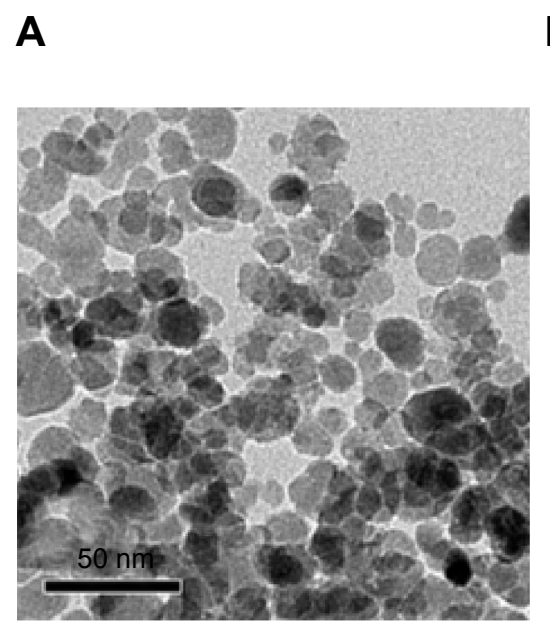
B Results

\section{Size}
Standard
(d.nm): \% intensity: deviation (d.nm):

$\begin{array}{rllll}\text { z-average (d.nm): } 64.87 & \text { Peak 1: } & 76.04 & 100.0 & 26.06 \\ \text { Pdl: } 0.152 & \text { Peak 2: } & 0.000 & 0.0 & 0.000 \\ \text { Intercept: } 0.953 & \text { Peak 3: } & 0.000 & 0.0 & 0.000\end{array}$

Result quality: Good

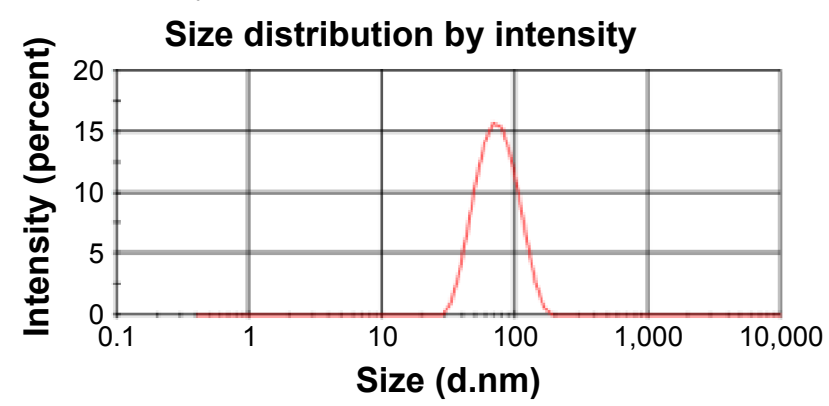

Figure I Characterization of $\mathrm{Fe}_{3} \mathrm{O}_{4}$

Notes: (A) TEM of the $\mathrm{Fe}_{3} \mathrm{O}_{4}$ nanoparticles that were high electron density with a diameter of approximately $20 \mathrm{~nm}$. (B) Hydrodynamic diameter distribution of $\mathrm{Fe}_{3} \mathrm{O}_{4}$ nanoparticles in PBS as measured by a particle size analyzer.

Abbreviations: TEM, transmission electron microscopy; PDI, polydispersity index; PBS, phosphate-buffered saline.
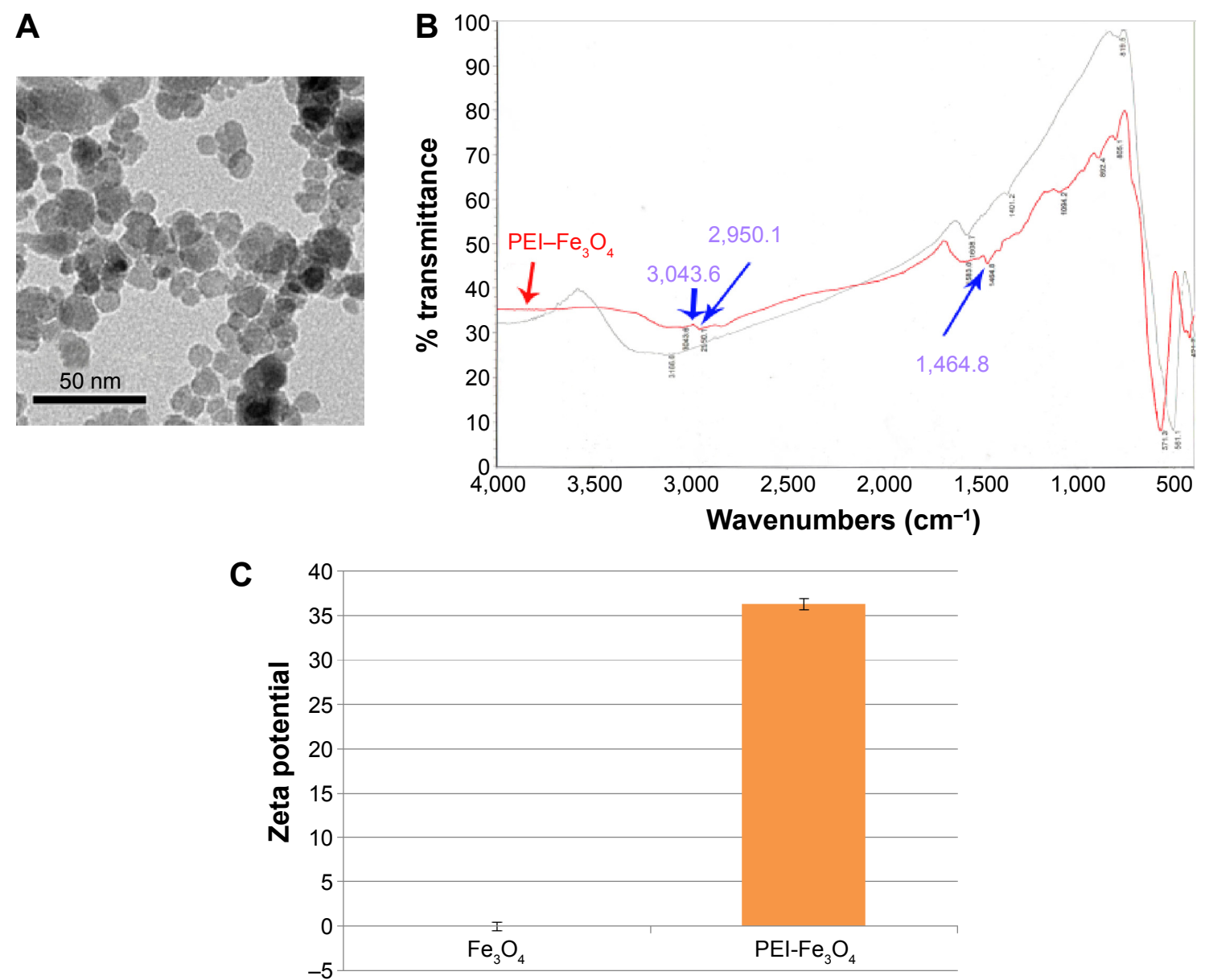

Figure 2 Characterization of $\mathrm{PEI}-\mathrm{Fe}_{3} \mathrm{O}_{4}$ nanoparticles.

Notes: (A) TEM of the PEI- $\mathrm{Fe}_{3} \mathrm{O}_{4}$ nanoparticles whose shape and size were similar to those of the $\mathrm{Fe}_{3} \mathrm{O}_{4}$ nanoparticles. (B) FTIR spectra of $\mathrm{PEI}-\mathrm{Fe}_{3} \mathrm{O}_{4}$ magnetic nanoparticles. The black curve is the $\mathrm{Fe}_{3} \mathrm{O}_{4}$, and the red curve is the $\mathrm{PEI}-\mathrm{Fe}_{3} \mathrm{O}_{4}$. Three blue arrows respectively indicate three characteristic peaks of PEI located at $3,043.6 \mathrm{~cm}^{-1}, 2,950.1 \mathrm{~cm}^{-1}$, and $\mathrm{I}, 464.8 \mathrm{~cm}^{-1}$. (C) The zeta potential of $\mathrm{Fe}_{3} \mathrm{O}_{4}$ and $\mathrm{PEI}-\mathrm{Fe}_{3} \mathrm{O}_{4}$ in $\mathrm{pH}$ 7. The surface charge of $\mathrm{Fe}_{3} \mathrm{O}_{4}$ was $0 \pm 0.5 \mathrm{mV}$ and turned into $36.3 \pm 0.6 \mathrm{mV}$ after being modified with PEI.

Abbreviations: TEM, transmission electron microscopy; PEI, polyetherimide; FTIR, Fourier transform infrared spectroscopy. 


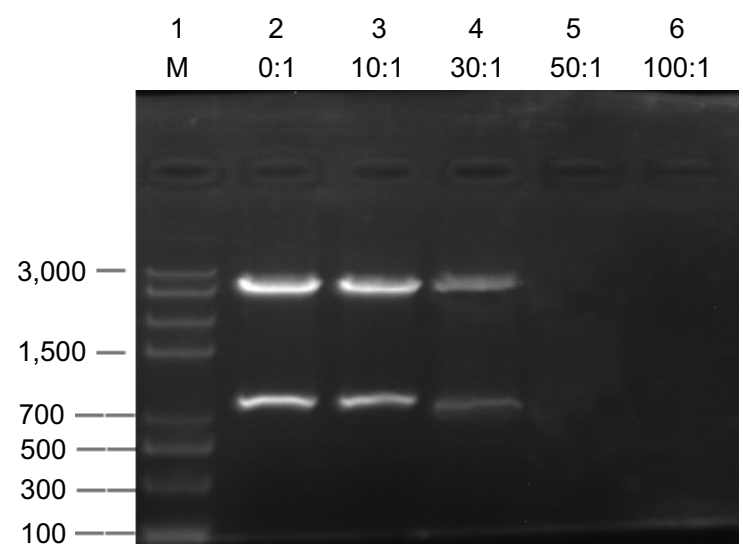

Figure 3 Image of agarose gel electrophoresis of plasmid DNA, free and complexed with $\mathrm{PEI}-\mathrm{Fe}_{3} \mathrm{O}_{4}$ nanoparticles.

Notes: I, marker; 2, NP:P-EGFP (0:1); 3, I0:1; 4, 30:1; 5, 50:1; 6, 100:1.

Abbreviations: $\mathrm{PEI}$, polyetherimide; NP, nanoparticle.

\section{Assessment of the capability of $\mathrm{PEI}-\mathrm{Fe}_{3} \mathrm{O}_{4}$ nanoparticles to be combined with plasmid}

Agarose gel electrophoresis (Figure 3) showed that DNA could be effectively bound to $\mathrm{Fe}_{3} \mathrm{O}_{4}$ MNPs modified with PEI. When the ratio of $\mathrm{PEI}-\mathrm{Fe}_{3} \mathrm{O}_{4}$ and plasmids was 50:1, no obvious DNA strips were seen, whereas obvious DNA strips were seen in agarose gel when the ratios were $0: 1,10: 1,30: 1$, and the band in the lane with 30:1 was significantly weak. These results suggested that $\mathrm{PEI}-\mathrm{Fe}_{3} \mathrm{O}_{4}$ could be combined with all plasmids in the system at the ratio of at least 50:1 and beyond, and 50:1 was the optimal ratio.

\section{Preparation and characteristics detection of gene-loaded IMANS (C225-IFNG- IMANS)}

TEM analysis showed that the self-prepared C225-IFNGIMANS were approximately spherical and uniform in size. The magnetite materials with a high electron density were incorporated well in the cores of ANS (Figure 4A). DLS showed that the hydrodynamic size of the IFNG-IMANS was $189.5 \pm 2.4 \mathrm{~nm}$ and the polydispersity index was 0.005 (Figure 4B). The hydrodynamic size of C225-IFNG-IMANS was $211.9 \pm 3.1 \mathrm{~nm}$ and the polydispersity index was 0.201 (Figure 4C). The surface charge of IFNG-MANS was $-37.9 \pm 0.4 \mathrm{mV}$ and slightly reduced to $-40.2 \pm 0.7 \mathrm{mV}$ for C225-IFNG-IMANS (Figure 4D).

\section{A}

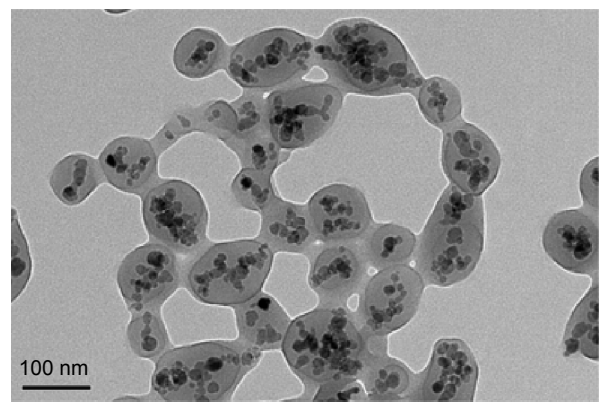

C
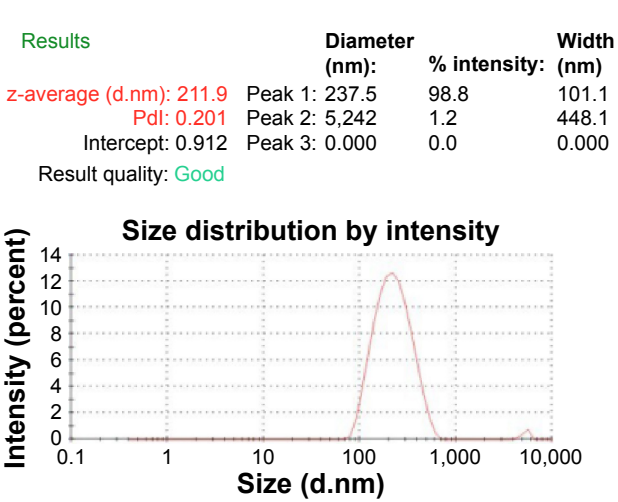

B

\begin{tabular}{rlll}
\multicolumn{1}{r|}{ Results } & \multicolumn{1}{c}{$\begin{array}{l}\text { Size } \\
\text { (d.nm): }\end{array}$} & $\begin{array}{l}\text { Standard intensity: } \\
\text { deviation (d.nm): }\end{array}$ \\
z-average (d.nm): 189.5 & Peak 1: 197.3 & 100.0 & 45.60 \\
Pdl: 0.005 & Peak 2: 0.000 & 0.0 & 0.000 \\
Intercept: 0.883 & Peak 3: 0.000 & 0.0 & 0.000
\end{tabular}

Result quality: Good

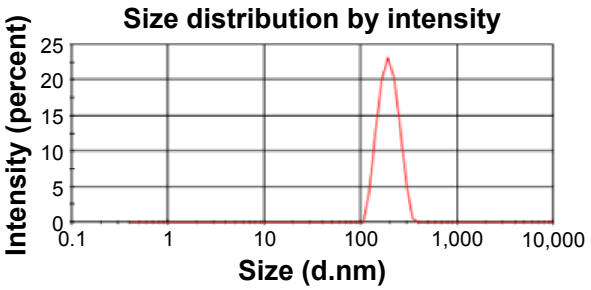

D

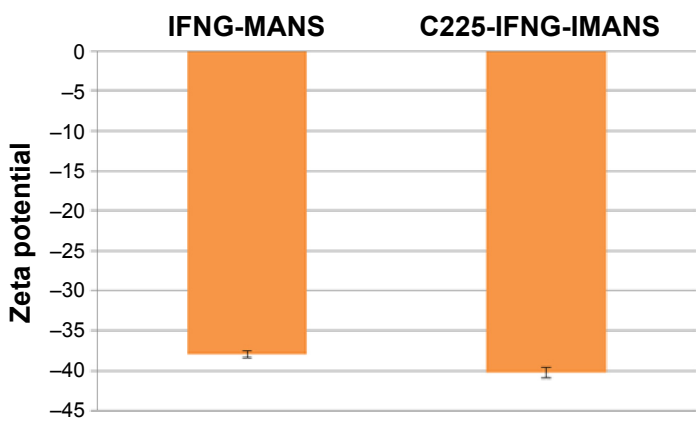

Figure 4 Characterization of IFNG-MANS and C225-IFNG-IMANS.

Notes: (A) TEM of gene-loaded IMANS. (B) Hydrodynamic diameter distribution of IFNG-MANS in PBS as measured by a particle size analyzer. (C) Hydrodynamic diameter distribution of C225-IFNG-IMANS in PBS as measured by a particle size analyzer. (D) The zeta potential of IFNG-MANS and C225-IFNG-IMANS in pH 7.

Abbreviations: TEM, transmission electron microscopy; PBS, phosphate-buffered saline; MANS, magnetic albumin nanospheres; IMANS, immunomagnetic albumin nanospheres; PDI, polydispersity index; C225, cetuximab. 
The surface charge of IFNG-MANS was $37.9 \pm 0.4 \mathrm{mV}$ and slightly reduced to $40.2 \pm 0.7 \mathrm{mV}$ for C225-IFNG-IMANS. MANS are ANS that are wrapped with MNPs. ANS are endogenous carriers that are free of the hemolytic or immunogenic problems of albumin. Therefore, ANS may be highly efficient and safe for drug and gene delivery. ${ }^{33-35}$ Many researchers have successfully applied albumin as a drug-delivery system. Additionally, albumin paclitaxel nanospheres (Abraxane) was approved by the US Food and Drug Administration in 2005 for the treatment of metastatic breast cancer based on extensive preclinical and clinical investigations, and this drug has recently been approved for the treatment of NSCLC. ANS have also been successfully used as a gene delivery system. Abbasi et al have used ANS to successfully deliver siRNA into MCF-7 breast cancer cells. ${ }^{36}$

\section{Cell transfection experiment}

Transfection experiments showed that $\mathrm{PEI}-\mathrm{Fe}_{3} \mathrm{O}_{4}$ nanoparticles and C225-EGFR-IMANS can effectively deliver plasmid pEGFP into GLC-82 cells and HEK293 cells, which express GFP well (Figure 5A). The transfection efficiency of the PEI-Fe $\mathrm{O}_{4}$ and Lipofectamine of the HEK293 group were
A
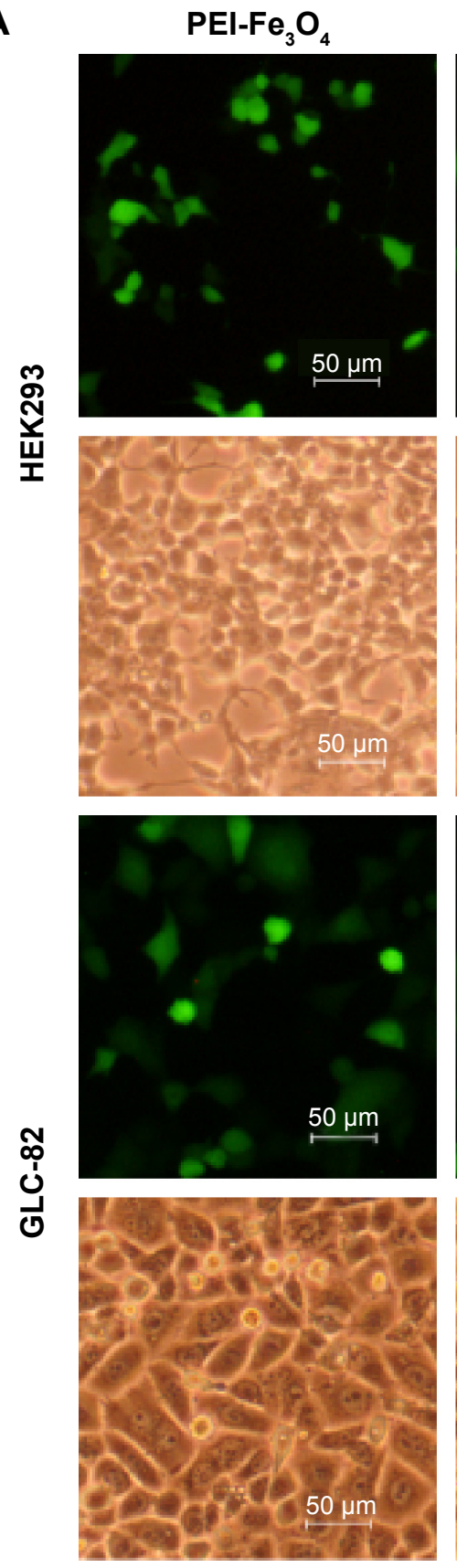

C225-IFNG-IMANS
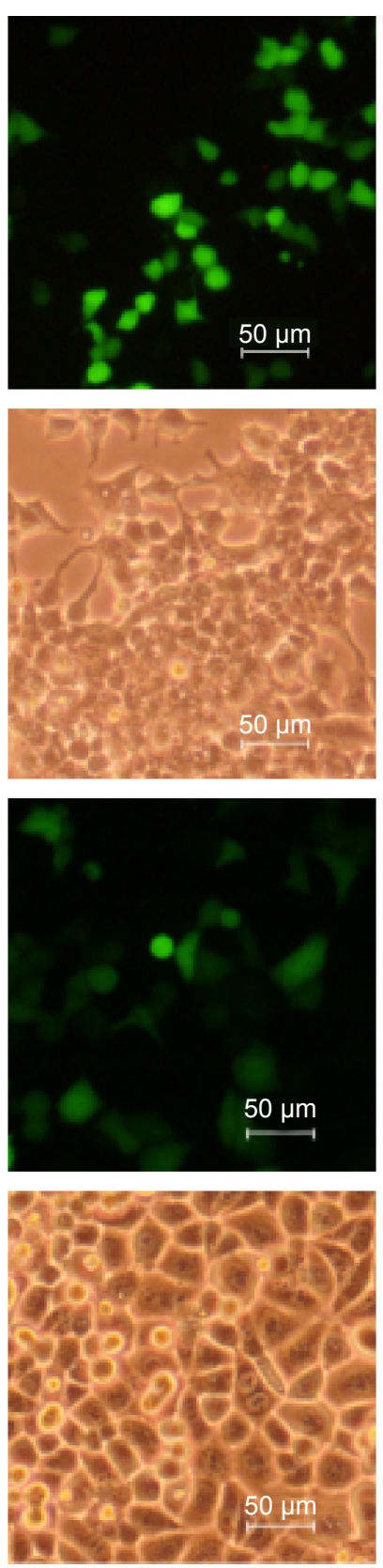

\section{Lipofectamine}
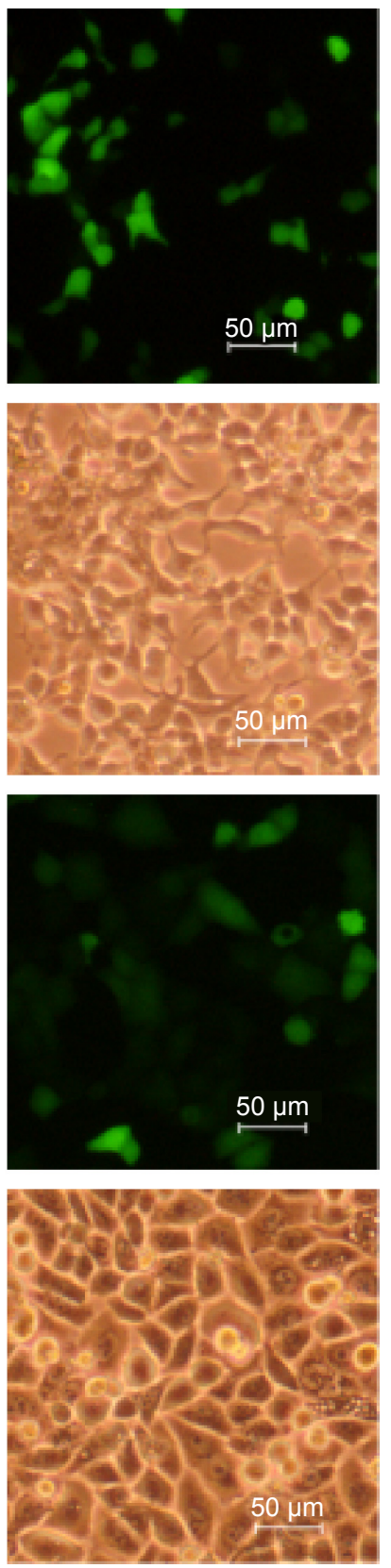

Figure 5 (Continued) 
B
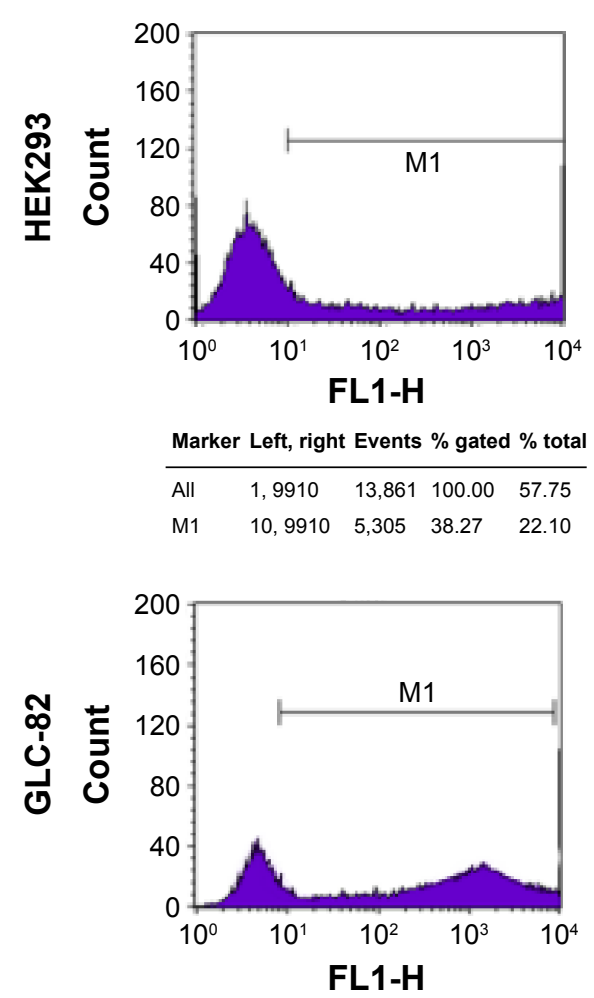

Marker Left, right Events \% gated \% total

\begin{tabular}{lllll}
\hline All & 1,9910 & 16,928 & 100.00 & 70.53
\end{tabular}

$\begin{array}{lllll}\text { M1 } & 8,8817 & 6,517 & 38.50 & 27.15\end{array}$
C225-IFNG-IMANS

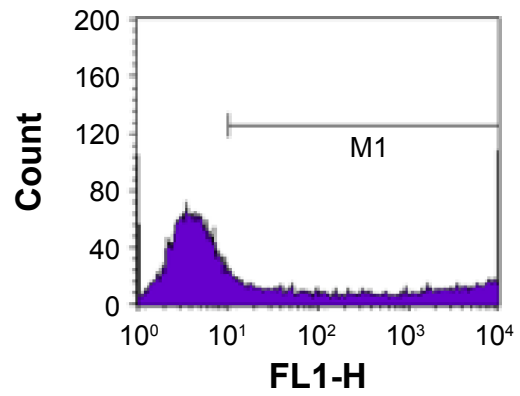

Marker Left, right Events \% gated \% total

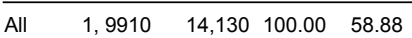

M1 $\quad 10,9910 \quad 5,545 \quad 39.24 \quad 23.10$

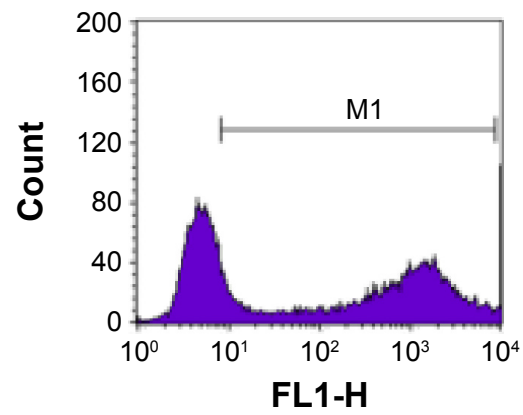

Marker Left, right Events \% gated \% total

\begin{tabular}{lllll}
\hline All & 1,9910 & 16,922 & 100.00 & 70.51
\end{tabular}

M1 $\quad 8,8817 \quad 9,798 \quad 57.90 \quad 40.82$
Lipofectamine

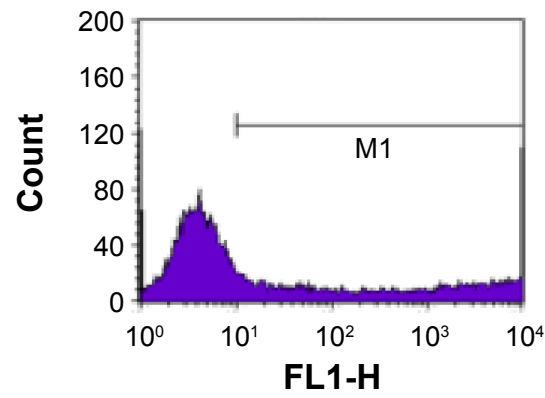

Marker Left, right Events \% gated \% total

\begin{tabular}{lllll}
\hline All & 1,9910 & 13,972 & 100.00 & 58.22
\end{tabular}

$\begin{array}{lllll}\text { M1 } & 10,9910 & 5,410 & 38.72 & 22.54\end{array}$

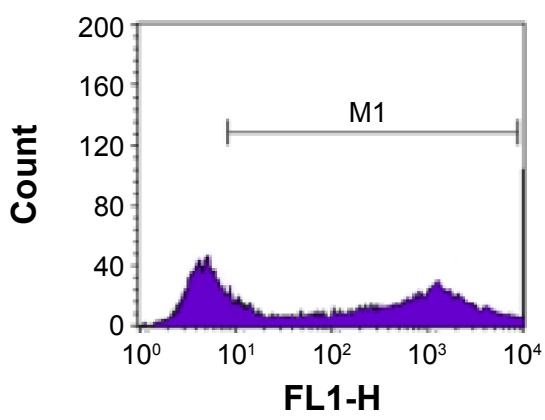

Marker Left, right Events \% gated \% total \begin{tabular}{lllll}
\hline All & 1,9910 & 16,828 & 100.00 & 70.12
\end{tabular} $\begin{array}{lllll}\text { M1 } & 8,8817 & 6,388 & 37.96 & 26.62\end{array}$

Figure 5 Transfection efficiency observation of nanoparticles.

Notes: (A) GLC-82 and HEK293 cells observed under a fluorescence microscope $(\times 100)$. (B) Transfection efficiency of PEI-Fe $\mathrm{O}_{4}$ nanoparticles and C225-IFNG-IMANS. Abbreviations: IMANS, immunomagnetic albumin nanospheres; PEI, polyetherimide; C225, cetuximab.

the same as that of the GLC-82 group, and the transfection efficiency of the C225-IFNG-IMANS of the GLC-82 group was higher than that of the HEK293 group (Figure 5B).

Gene therapy using nanocarriers is a promising new tumor treatment strategy. Tumor gene therapy using viral and non-viral vectors has been intensively studied, but non-viral gene therapy has been largely ignored in the past due to its inefficient gene delivery, toxicity, and short-term gene expression. However, recent advances in nanoparticle technology and in the genetic material to be transferred are dramatically changing the popularity of this gene transfer methodology. MNPs have been recently developed as a new non-viral gene vector and have shown satisfactory biocompatibility and a large specific surface area..$^{37,38}$ Therefore, MNPs can carry foreign DNA into cells. Because nanoparticles are bound to DNA via electrostatic attraction, the surface of $\mathrm{Fe}_{3} \mathrm{O}_{4}$-MNPs was coated with the positively charged PEI in our experiment, which can better absorb the negatively charged DNA molecules and effectively carry the pEGFR expression plasmid to GLC-82 cells.

\section{Targeting evaluation of C225-IFNG- IMANS in vitro}

\section{Prussian blue staining}

Prussian blue staining demonstrated that the cellular iron density (blue particles) was higher in GLC-82 cells that were incubated with C225-IFNG-IMANS (Figure 6A) whereas iron particles were not observed obviously within the cells incubated with IFNG-IMANS (Figure 6B). Because HL7702 cells do not express EGFR, neither the non-C225-targeting groups (Figure 6C) nor C225-targeting groups (Figure 6D) displayed obvious iron particles.

\section{Immunofluorescence experiments}

Immunofluorescence staining showed that the green fluorescence in the GLC-82 cells of the C225-targeting groups, but not in the non-C225-targeting groups (Figure 7). The C225-targeting groups and non-C225-targeting groups (Figure 7) of the HL7702 cells did not show green fluorescence. 
A

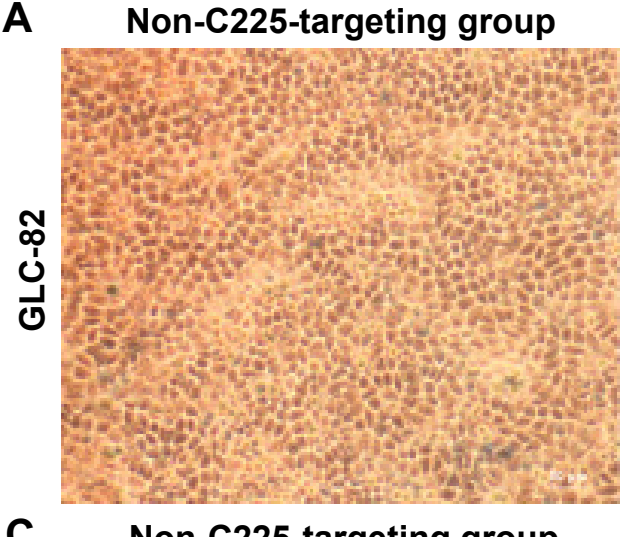

C

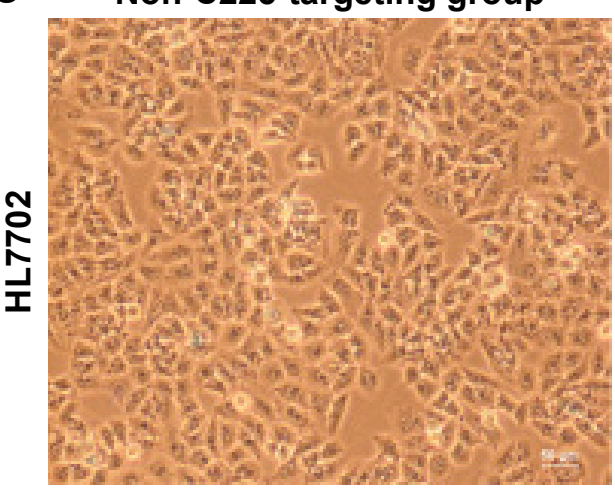

B

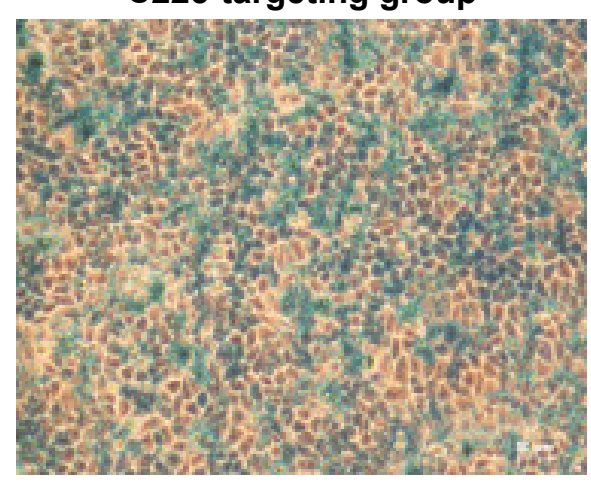

D

C225-targeting group

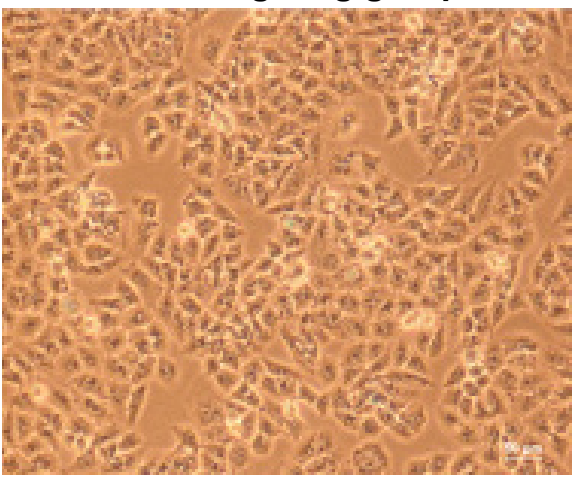

Figure 6 Prussian blue-stained cells after treatment with different probe groups ( $\times 100$ magnification).

Notes: (A) Non-C225-targeting groups of GLC-82 cells. (B) C225-targeting groups of GLC-82 cells. (C) Non-C225-targeting groups of HL7702 cells. (D) C225-targeting groups of HL7702 cells.

Abbreviation: C225, cetuximab.

\section{MRI in vitro}

The MRI T2 signal intensity of GLC-82 cells significantly decreased after incubation with C225-IFNG-IMANS, but did not markedly decrease after incubation with IFNGIMANS. The signal intensity of HL7702 cells, which do not express EGFR, did not change in either of the groups (Figure 8A). The $\mathrm{T} 2$ relaxation time of the $\mathrm{C} 225$-targeting groups was shorter than the non-C225-targeting groups for GLC-82 cells, but did not differ for HL7702 cells (Figure 8B) $(P<0.05)$.

In this study, we assessed the targeting of C225IFNG-IMANS to GLC-82 cells by conducting the above experiments in vitro. Retaining the specific immunoreactivity of monoclonal antibodies is very important when conjugating the monoclonal antibodies to the surface of nanoparticles. Lee et al ${ }^{39}$ prepared methotrexate-loaded immuno-microspheres and evaluated their targeting of an antigen-positive human leukemia cell line. BSA-NS coated with monoclonal antibodies were more readily trapped in the tumor tissue of Lewis lung carcinoma-bearing mice than BSA-nanospheres coated with mouse IgG at 24 hours after injection. ${ }^{40}$ Therefore, the targeting ability of the monoclonal antibodies was retained after they were conjugated to the MANS.

\section{Heating test of $\mathrm{Fe}_{3} \mathrm{O}_{4}$ MNPs and C225- IFNG-IMANS}

The thermodynamic test of $\mathrm{Fe}_{3} \mathrm{O}_{4}$ MNPs in vitro showed that when placed in AMF (200 kHz, $20 \mathrm{~A})$, the corresponding magnetic fluid with different concentrations could rise to a steady temperature ranging from $39^{\circ} \mathrm{C}$ to $56^{\circ} \mathrm{C}$ within 50 minutes, at which point the temperature of the solution remained stable (Figure 9A).

Figure 9B shows the heating curve of the C225-IFNGIMANS at different concentrations. Exposure to the magnetic field rapidly warmed fluids of all concentrations to a stable temperature. The concentration of the solution positively correlated with the maximum temperature. Among the tested concentrations, the $0.25 \mathrm{mg} / \mathrm{mL}$ solution rapidly warmed within 5 minutes, and then gradually stabilized at a temperature of approximately $44^{\circ} \mathrm{C}$, which is appropriate for tumor treatment but does not harm normal tissues. Thus, $0.25 \mathrm{mg} / \mathrm{mL}$ was selected for subsequent magnetic induction hyperthermia experiments. A comparison of Figure 8A 

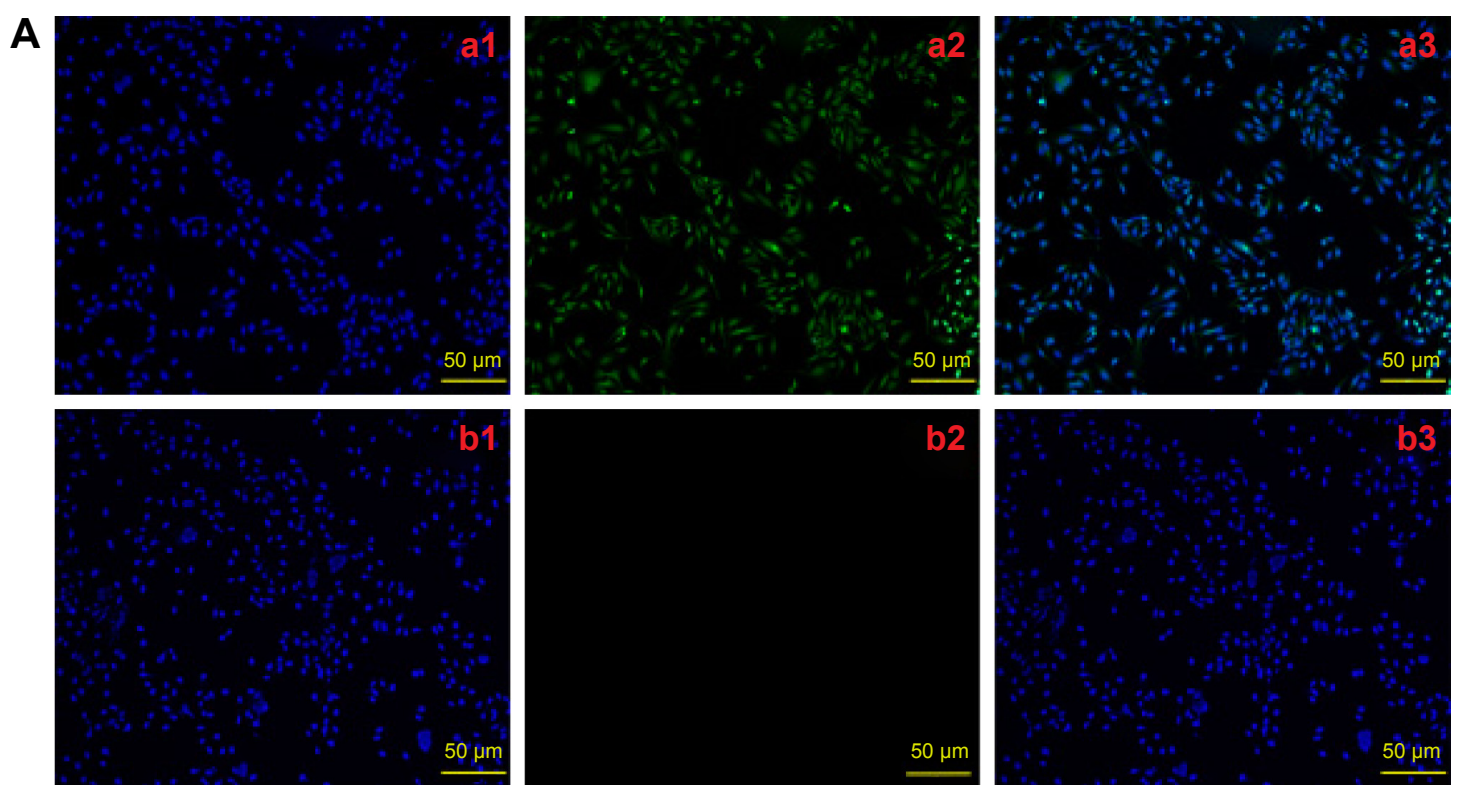

B
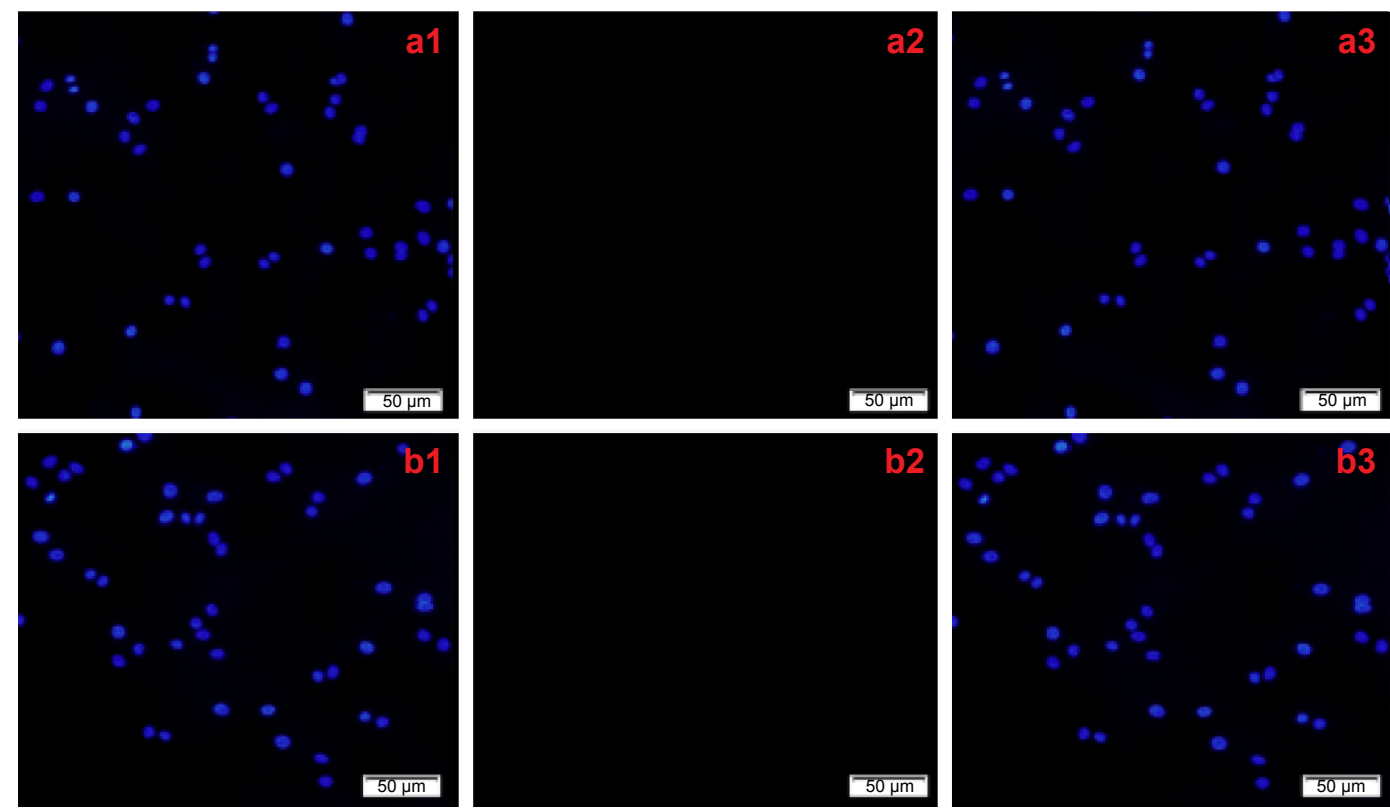

Figure 7 The specific interaction between cells and C225-IFNG-IMANS.

Notes: (A) GLC-82 cells immunofluorescence experiments: a, C225 targeting groups; b, non-C225 targeting groups. I, DAPI fluorescence; 2 , Alexa Fluor 488 fluorescence; 3, merged fluorescence (I and 2). (B) HL7702 cells immunofluorescence experiments: a, C225 targeting groups; b, non-C225 targeting groups. I, DAPI fluorescence; 2, Alexa Fluor 488 fluorescence; 3 , merged fluorescence ( 1 and 2).

Abbreviations: DAPI, 4',6-diamidino-2-phenylindole; C225, cetuximab.

and $\mathrm{B}$, showed the albumin. Coating did not affect the heating capacity of $\mathrm{Fe}_{3} \mathrm{O}_{4}$ nanoparticles.

\section{The therapeutic effects on GLC-82 cells CCK8 assay}

The cell RGRs of eight groups after 24 hours, 48 hours, and 72 hours are shown in Figure 10. The experimental and negative control groups significantly differed $(P<0.05)$. Compared with the single therapy groups and the other two therapy groups, the nanosized C225-IFNG-IMANS complex combined with MFH could more significantly inhibit the proliferation of GLC-82 cells $(P<0.05)$.

\section{Flow cytometry assay}

GLC-82 cells were stained with Annexin V and PI and subjected to flow cytometry to detect the ability of various treatments to induce apoptosis.

Generally, cells typically have an intact cell membrane that cannot be stained by PI. However, the externalization of phosphatidylserine changes the cell membrane (membrane 

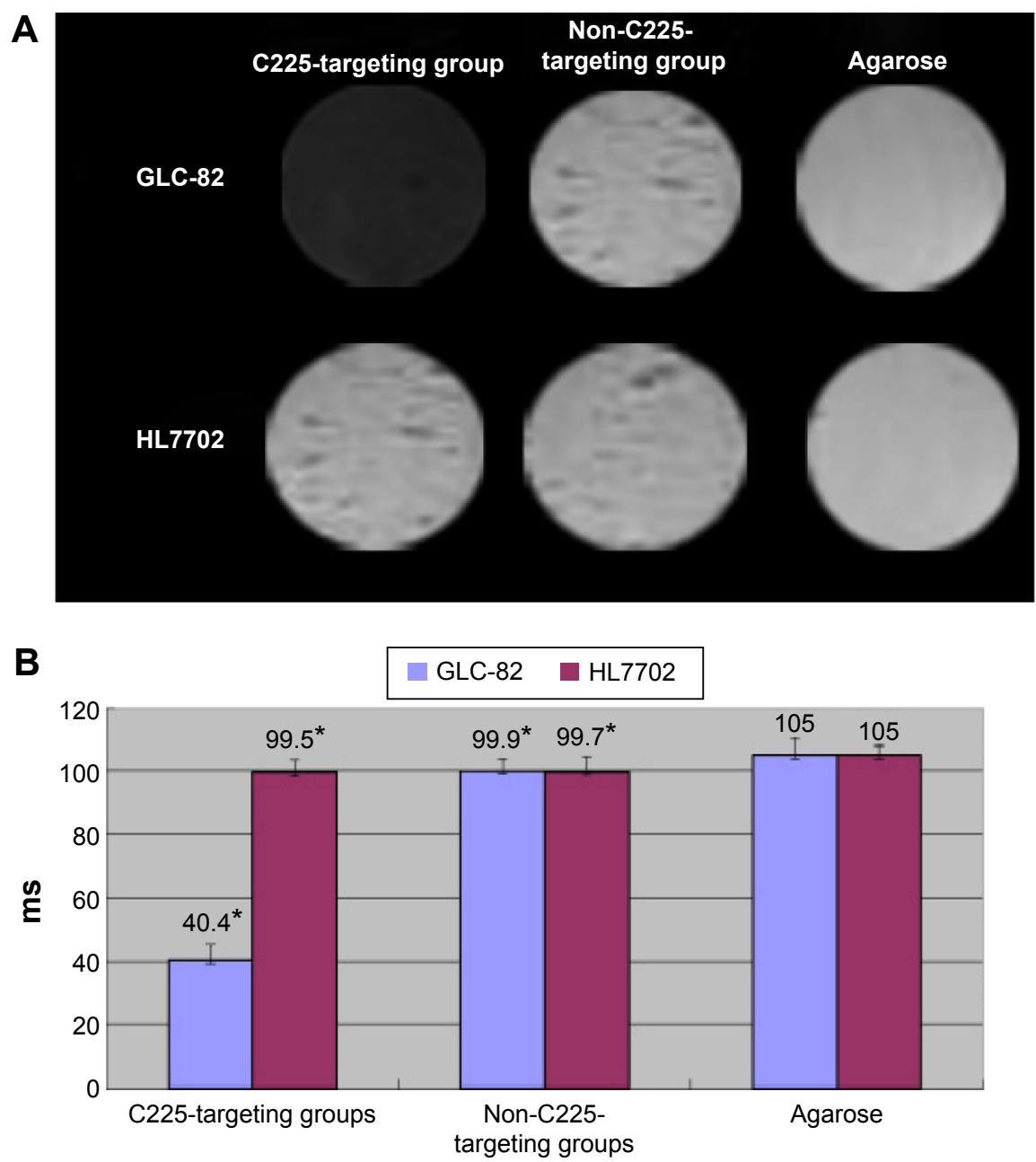

T2 relaxation time

Figure 8 In vitro MRI.

Notes: (A) In vitro MRI of GLC-82 and HL7702 cells after treatment with different probe groups. (B) T2 relaxation time of GLC-82 and HL7702 cells after treatment with different probe groups (* indicates $P<0.05$ ).

Abbreviations: MRI, magnetic resonance imaging; $C 225$, cetuximab.
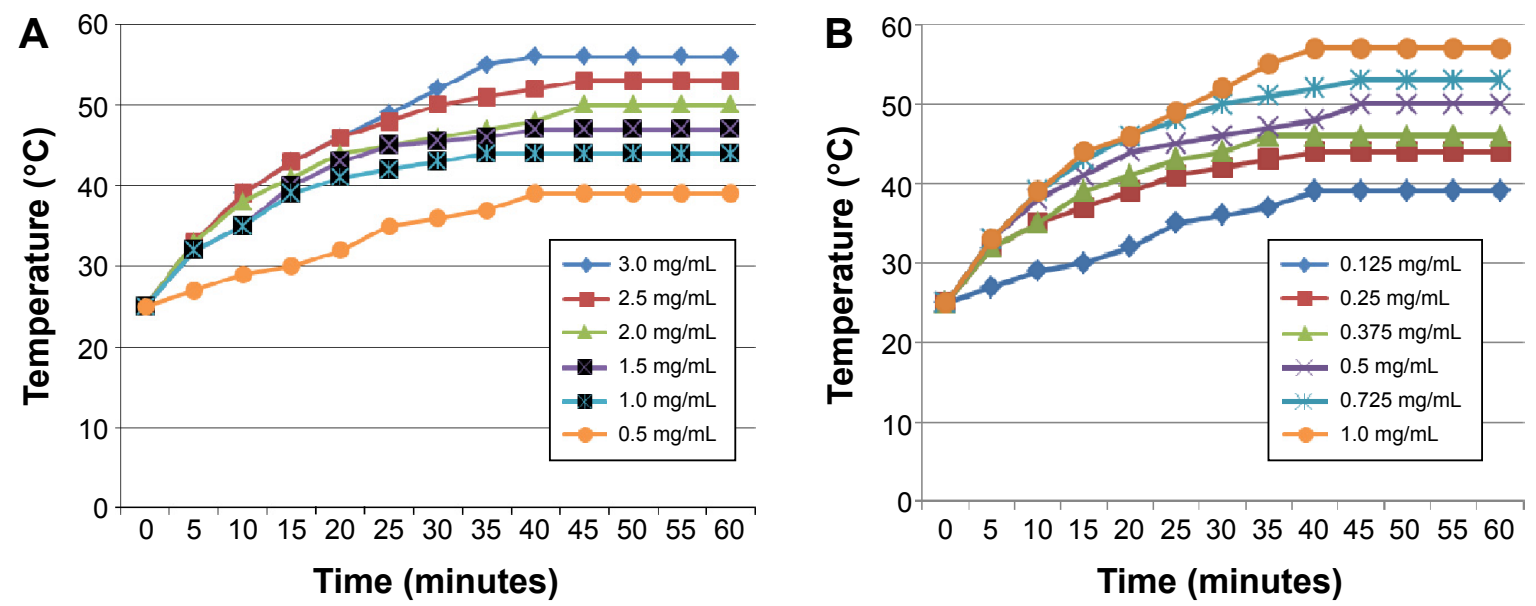

Figure 9 Heating test of $\mathrm{Fe}_{3} \mathrm{O}_{4}$ nanoparticles and C225-IFNG-IMANS in vitro.

Notes: (A) Heating test of $\mathrm{Fe}_{3} \mathrm{O}_{4}$ nanoparticles fluid in AMF in vitro. The concentration of $\mathrm{Fe}_{3} \mathrm{O}_{4}$ is 3.0, 2.5, 2.0, I.5, I.0, and 0.5 mg/mL. (B) Heating test of C225-IFNGIMANS fluid in AMF in vitro. The concentration of Fe in albumin nanospheres was $1.0,0.725,0.5,0.375,0.25$, and $0.125 \mathrm{mg} / \mathrm{mL}$.

Abbreviations: IMANS, immunomagnetic albumin nanospheres; AMF, alternating magnetic field; C225, cetuximab. 


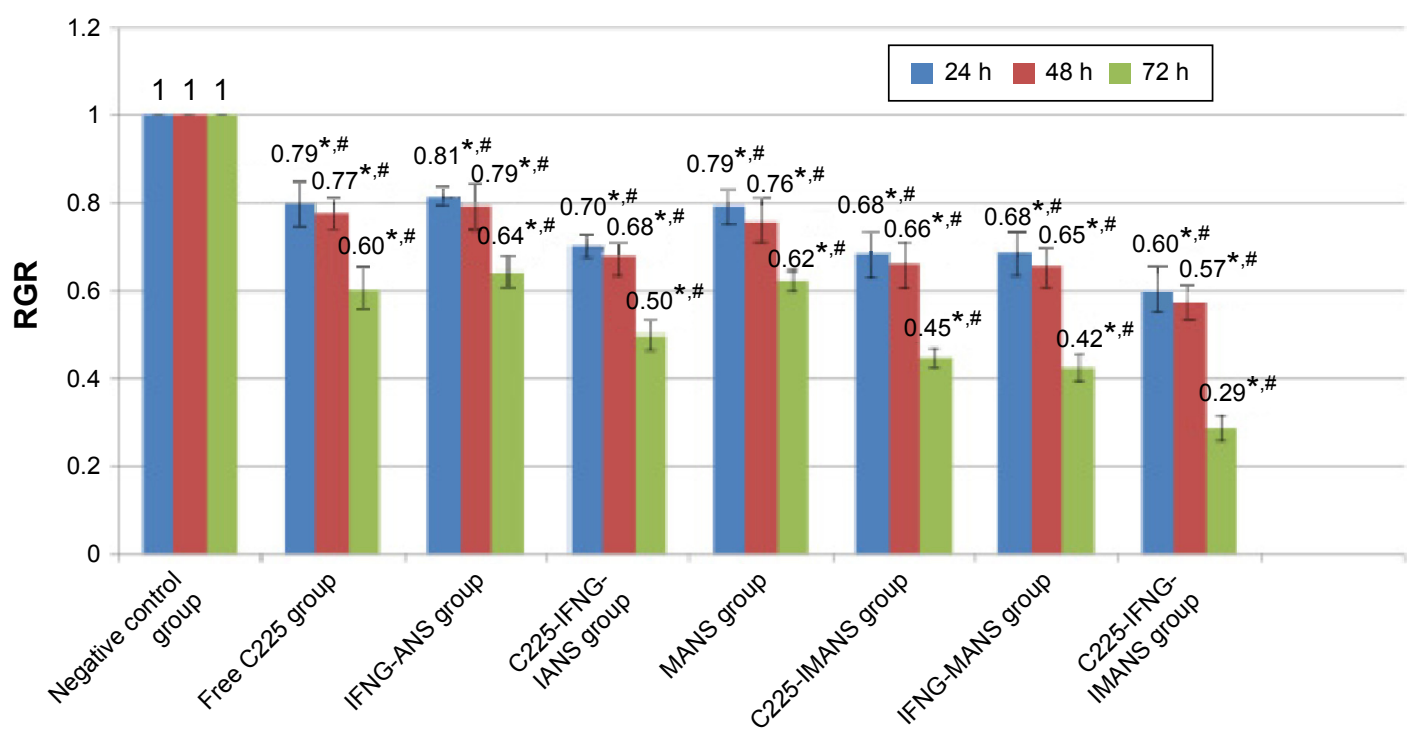

Figure 10 The results of the CCK 8 assay.

Notes: *Comparison between experimental group and negative control group, $P<0.05$. "Comparison between each of the experimental groups, $P<0.05$.

Abbreviations: CCK8, Cell Counting Kit-8; ANS, albumin nanospheres; MANS, magnetic albumin nanospheres; IMANS, immunomagnetic albumin nanospheres; h, hours; RGR, relative growth rate; $C 225$, cetuximab; IANS, albumin immuno-nanospheres.

phospholipids) during the early stages of apoptosis, which can be detected by Annexin V, but not PI due to the intact cell membrane. The membrane ruptures during late apoptosis, and PI can infiltrate the cells. Necrotic cells can be differentiated from apoptotic cells because they lose their membrane integrity, and their phosphatidylserine degrades. Cells positive for only PI are necrotic, whereas those positive for Annexin V and PI are in the late stages of apoptosis and those only positive for Annexin V are in the early stages of apoptosis.

Flow cytometry revealed apoptotic GLC-82 cells in all the experimental groups. The apoptotic indices were $12.2 \%$ in the free $\mathrm{C} 225$ group, $16.34 \%$ in the gene therapy group, $33.88 \%$ in the C225-targeted gene therapy group, $20.04 \%$ in the $\mathrm{MFH}$ group, $39.71 \%$ in the $\mathrm{C} 225$-targeted $\mathrm{MFH}$ group, 39.2\% in the gene therapy and MFH combination group, $67.68 \%$ in the C225-targeted gene therapy and MFH combination group, and $0.5 \%$ in the negative control group (Figure 11).

The results of the CCK 8 and flow cytometry assay both suggested that the novel approaches for NSCLC in combination with hyperthermia, gene therapy, and molecularly targeted therapy may be a potential method to treat tumors. However future studies should address remaining challenges, such as the targeting ability of C225-IFNG-IMANS in vivo, the molecular analysis of IFNG gene expression and the treatment effects of C225-IFNG-IMANS in vivo.

Studies in recent years have shown that single treatments are limited and not able to cure cancer alone. Multimodal therapy had been used more and more and exhibited more effectiveness in tumor treatment than single modality treatment. ${ }^{41-43}$ Combination treatments usually show synergistic effects which may observably improve therapeutic effects while reducing the side effects of each single treatment modality. In our study, the tumor-eliminating rate of MFH was greatly enhanced when combined with gene therapy and molecular targeting treatment. However, the mechanism of the combined treatment is inconclusive and the possibilities may be as follows. In our study, we found that with the anti-EGFR monoclonal antibody C225, either gene therapy or hyperthermia therapy brought more significant inhibition of growth and induction of apoptosis in GLC-82 cells than those groups without $\mathrm{C} 225$. The results showed that $\mathrm{C} 225$ coated MANS did not just have selective targeting of the expression of EGFR cells, but could also inhibit proliferation of lung cancer cells. The product of pDONR223-IFNG is INF $\gamma$. INF $\gamma$ exerts direct anti-tumor effects by inhibiting tumor cell proliferation, inducing differentiation, and promoting apoptosis $\mathrm{s}^{4,45}$ and exerts indirect anti-tumor effects by activating macrophages and natural killer cells, inducing the expression of major histocompatibility complex class I and class II molecules, enhancing the $\mathrm{T}$ cell-mediated death of tumor cells and inhibiting tumor angiogenesis. ${ }^{46}$ Hyperthermia in combination with other treatments was thought to affect sensitivity of tumors to other treatments mainly through microenvironment factors. ${ }^{47}$ In hyperthermia treatments, the tumor tissue is heated above $42^{\circ} \mathrm{C}$, the integrity of the cell membrane is damaged, and the penetrability increased, which causes cellular swelling. Hyperthermia also restrains the repair of DNA damage by 

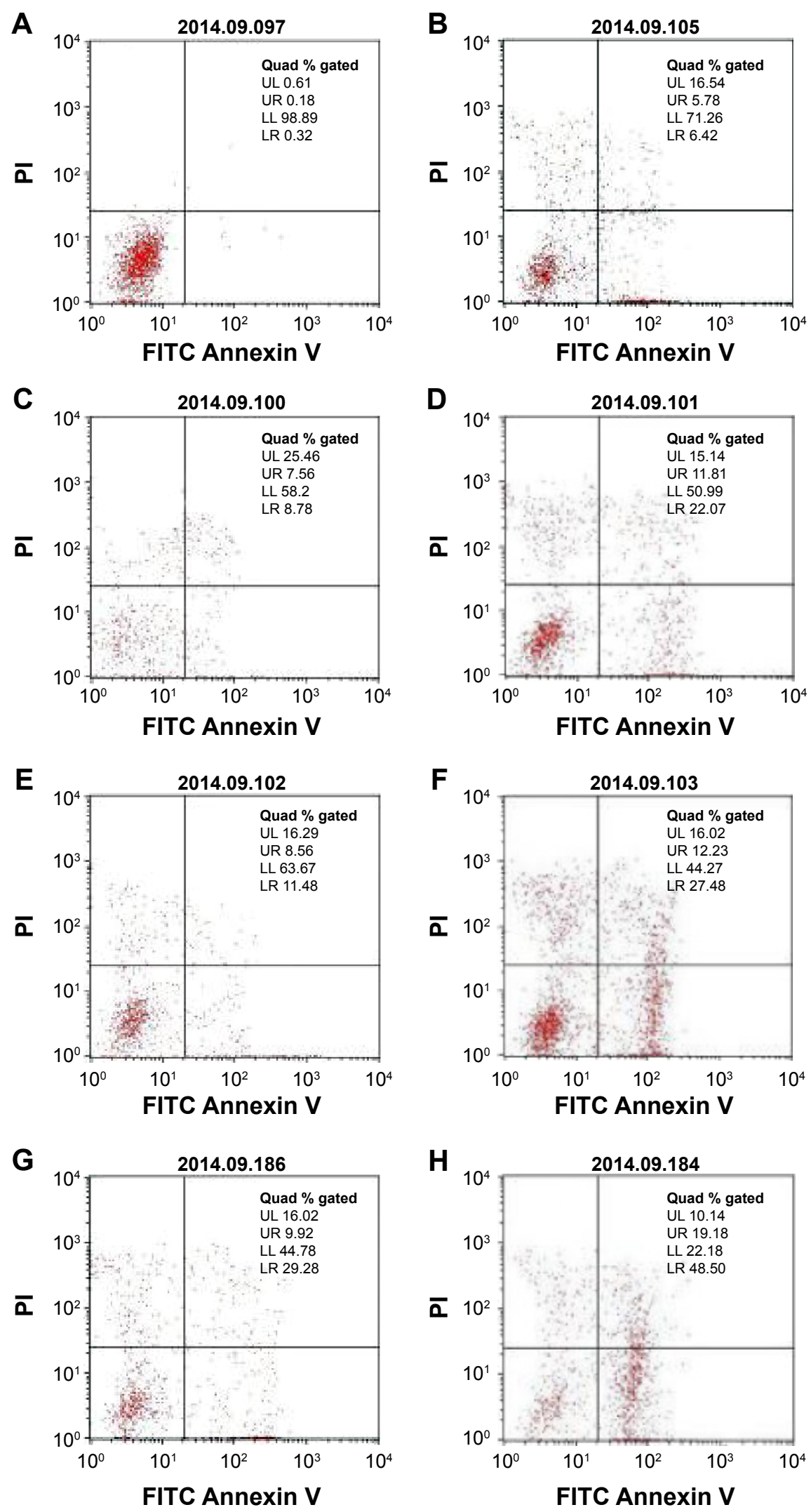

Figure II The apoptosis and necrosis of GLC-82 cells analyzed by flow cytometry after different treatments.

Notes: (A) Negative control group; (B) free C225 group (C225 solution); (C) gene therapy group (gene-loaded albumin nanospheres, IFNG-ANS); (D) C225-targeted gene therapy group (C225-IFNG-IANS); (E) MFH group (MANS); (F) C225-targeted MFH (C225-IMANS) group; (G) gene therapy and MFH combination group (IFNG-MANS); (H) C225-targeted gene therapy and MFH combination group (C225-IFNG-IMANS).

Abbreviations: ANS, albumin nanospheres; PI, propidium iodide; MANS, magnetic albumin nanospheres; IMANS, immunomagnetic albumin nanospheres; MFH, magnetic fluid hyperthermia; C225, cetuximab; FITC, fluorescein isothiocyanate; IANS, albumin immuno-nanospheres. 
gene therapy.$^{48}$ Lastly, heating had direct cytotoxic effects or induced tumor cells' apoptosis, which contributed to the therapeutic effects.

\section{Conclusion}

In this study, the PEI-Fe $\mathrm{O}_{4}$ MNPs were used as a novel gene vector and C225-IFNG-IMANS were successfully prepared. The ability of C225-IFNG-IMANS to target GLC-82 cells was evaluated. A CCK8 test and flow cytometry assay showed that the combination therapy was markedly superior to all tested monotherapies. We explored a new multiple therapy approach for lung cancer by combining thermal treatment, molecular targeted treatment, and gene treatments.

\section{Acknowledgment}

This project was supported by the National Natural Science Foundation of China $(30770584,81171452)$.

\section{Disclosure}

The authors report no conflicts of interest in this work.

\section{References}

1. Ou SI, Ho C. Treatment of Advanced Lung Cancer. Clinical Pulmonary Medicine. 2009;16(3):157-171.

2. Cohen-Sela E, Chorny M, Gutman D, Komemi S, Koroukhov N, Golomb G. Characterization of Monocytes-targeted nanocarriers Biodistribution in Leukocytes in ex vivo and in vivo Models. Nano Biomedicine and Engineering. 2010;2(2):91-99.

3. Anton E, Swetha K, Thomas W, Nicolosi R. Dextran-based nanocarriers as efficient media delivery vehicles to cell production bioreactors. Nano Biomedicine and Engineering. 2010;2(2):126-132.

4. Huang P, Li Z, Lin J, et al. Photosensitizer-conjugated magnetic nanoparticles for in vivo simultaneous magnetofluorescent imaging and targeting therapy. Biomaterials. 2011;32(13):3447-3458.

5. Gao G, Huang P, Zhang YX, Wang K, Qin W, Cui DX. Gram scale synthesis of superparamagnetic $\mathrm{Fe}_{3} \mathrm{O}_{4}$ nanoparticles and fluid via a facile solvothermal route. Cryst Eng Comm. 2011;13:1782-1785.

6. Shi S, Zhu X, Guo Q, et al. Self-assembled triblock copolymer mPEGPCL-gPEI for co-delivery of drug and DNA: synthesis and characterization in vitro. Int J Nanomedicine. 2012;7:1749-1759.

7. Guo QF, Liu TT, Yan X, et al. Synthesis and properties of a novel biodegradable poly (ester amine) copolymer based on poly(L-lactide) and low-molecular-weight polyethylenimine for gene delivery. Int J Nanomedicine. 2011;6:1641-1649.

8. Gou M, Men K, Zhang J, et al. Biodegradable heparin conjugated polyethylenimine nano-gel delivering VSVMP gene for C-26 colon carcinoma therapy. ACS Nano. 2010;4(10):5573-5584.

9. Wang X, Yu B, Wu Y, Lee RJ, Lee LJ. Efficient downregulation of CDK4 by novel lipid nanoparticle-mediated siRNA delivery. Anticancer Res. 2011;31(5):1619-1626.

10. Liu Y, Wang T, He F, et al. An efficient calcium phosphate nanoparticlebased nonviral vector for gene delivery. Int J Nanomedicine. 2011;6: 721-727.

11. de Jesus MB, Ferreira CV, de Paula E, Hoekstra D, Zuhorn IS. Design of solid lipid nanoparticles for gene delivery into prostate cancer. J Control Release. 2010;148(1):e89-e90.

12. Goyal R, Tripathi SK, Tyagi S, et al. Gellan gum-PEI nanocomposites as efficient gene delivery agents. J Biomed Nanotechnol. 2011;7(1):38-39.
13. Lee HJ, Nguyen YT, Muthiah M, et al. MR traceable delivery of p53 tumor suppressor gene by PEI-functionalized superparamagnetic iron oxide nanoparticles. J Biomed Nanotechnol. 2012;8(3):361-371.

14. Shundo C, Zhang H, Nakanishi T, Osaka T. Cytotoxicity evaluation of magnetite $\left(\mathrm{Fe}_{3} \mathrm{O}_{4}\right)$ nanoparticles in mouse embryonic stem cells. Colloids Surf BBiointerfaces. 2012;97:221-225.

15. Wang ZY, Wang L, Zhang J, Li YT, Zhang DS. A study on the preparation and characterization of plasmid DNA and drug-containing magnetic nanoliposomes for the treatment of tumors. Int J Nanomedicine. 2011;6:871-875.

16. Hirsch FR, Scagliotti GV, Langer CJ, Varella-Garcia M, Franklin WA. Epidermal growth factor family of receptors in preneoplasia and lung cancer: perspectives for targeted therapies. Lung Cancer. 2003;41 Suppl 1: S29-S42.

17. Cunningham D, Hummblet Y, Siena VS, et al. Cetuximab monotherapy and cetuximab plus irinotecan in irinotecan-refractory metastatic colorectal cancer. $N$ Engl J Med. 2004;351(4):337-345.

18. Pirker R, Pereira JR, Szczesna A, et al. Cetuximab plus chemotherapy in patients with advanced non-small cell cancer (FLEX): An open label randomized phase III trial. Lancet. 2009;373(9674):1525-1531.

19. Fukuda S, Pelus LM. Survivin, a cancer target with an emerging role in normal adult tissues. Mol Cancer Ther. 2006;5(5):1087-1098.

20. Gatzemeier U, von Pawel J, Vynnychenko I, et al. First-cycle rash and survival in patients with advanced non-small-cell lung cancer receiving cetuximab in combination with first-line chemotherapy: a subgroup analysis of date from the FLEX phase 3 study. Lancet Oncol. 2011; 12(1):30-37.

21. Heigener DF, Pereira JR, Felip E, et al. Weekly and every 2 weeks cetuximab maintenance therapy after platinum-based chemotherapy plus cetuximab as first-line treatment for non-small cell lung cancer: randomized non-comparative phase IIIb NEXT trial. Target Oncol. 2015;10(2):255-265.

22. Tang QS, Zhang DS, Cong XM, Wan ML, Jin LQ. Using thermal energy produced by irradiation of $\mathrm{Mn}-\mathrm{Zn}$ ferrite magnetic nanoparticles (MZF-NPs) for heat-inducible gene expression. Biomaterials. 2008;29(17):2673-2679.

23. Muller BG, Leuenberger H, Kissel T. Albumin nanospheres as carriers for passive drug targeting: an optimized manufacturing technique. Pharm Res. 1996;13(1):32-37.

24. McBanin SC, Yiu HH, Dobson J. Magnetic nanoparticles for gene and drug delivery. Int J Nanomed. 2008;3(2):169-180.

25. Hyeon T. Chemical synthesis of magnetic nanoparticles. Chem Commun (Camb). 2003;(8):927-934.

26. Yiu HH, McBain SC, Lethbridge ZA, Lees MR, Dobson J. Preparation and characterization of polyethylenimine-coated $\mathrm{Fe}_{3} \mathrm{O}_{4}$-MCM-48 nanocomposite particles as a novel agent for magnet-assisted transfection. J Biomed Mater Res A. 2010;92(1):386-392.

27. Veiseh O, Sun C, Fang C, et al. Specific targeting of brain tumors with an optical/magnetic resonance imaging nanoprobe across the bloodbrain barrier. Cancer Res. 2009;69(15):6200-6207.

28. Olariu CI, Yiu HH, Bouffier L, et al. Multifunctional $\mathrm{Fe}_{3} \mathrm{O}_{4}$ nanoparticles for targeted bi-modal imaging of pancreatic cancer. J Mater Chem. 2011; 21(34):12650-12659.

29. Wang D, Lin Y, Gu LX. Study on Properties of nanosized antimony doped tin oxide suspension. China Powder Science and Technology. 2004; $1: 10-13$.

30. Gao F, Pan BF, Zheng WM, Ao LM, Gu HC. Study of streptavidin coated onto PAMAM dendrimer modified magnetite nanoparticles. Journal of Magnetism and Magnetic Materials. 2005;293(1):48-54.

31. Goyal R, Bansal R, Tyagi S, Shukla Y, Kumar P, Gupta KC. 1,4-Butanediol diglycidyl ether (BDE)-crosslinked PEI-g-imidazole nanoparticles as nucleic acid-carriers in vitro and in vivo. Mol Biosyst. 2011;7(6): 2055-2065.

32. Lin M, Huang J, Zhang J, et al. The therapeutic effect of PEI$\mathrm{Mn}_{0.5} \mathrm{Zn}_{0.5} \mathrm{Fe}_{2} \mathrm{O}_{4}$ nanoparticles/pEgr1-HSV-TK/GCV associated with radiation and magnet-induced heating on hepatoma. Nanoscale. 2013;5(3): 991-1000. 
33. Anhorn MG, Wagner S, Kreuter J, Langer K, Briesen H. Specific targeting of HER2 overexpressing breast cancer cells with doxorubicinloaded trastuzumab-modified human serum albumin nanoparticles. Bioconjug Chem. 2008;19(12):2321-2331.

34. Elsadek B, Kratz F. Impact of albumin on drug delivery-new applications on the horizon. J Control Release. 2012;157(1):4-28.

35. Steinhauser IM, Langer K, Strebhardt KM, Spänkuch B. Effect of trastuzumab-modified antisense oligonucleotide-loaded human serum albumin nanoparticles prepared by heat denaturation. Biomaterials. 2008;29(29):4022-4028.

36. Abbasi S, Paul A, Prakash S. Investigation of siRNA-loaded polyethylenimine-coated human serum albumin nanoparticle complexes for the treatment of breast cancer. Cell Biochem Biophys. 2011;61(2): 277-287.

37. Dey S, Maiti TK. Superparamagnetic Nanoparticles and RNAiMediated Gene Silencing: Evolving Class of Cancer Diagnostics and Therapeutics. Journal of Nanomaterials. 2012:129107.

38. Liu YX, Chen ZP, Wang J. Systematic evaluation of biocompatibility of magnetic $\mathrm{Fe}_{3} \mathrm{O}_{4}$ nanoparticles with six different mammalian cell lines. Journal of Nanoparticle Research. 2011;13:199-212.

39. Lee KC, Lee YJ, Kim WB, Cha CY. Monoclonal antibody-based targeting of methotrexate-loaded microspheres. International Journal of Pharmaceutics. 1990;59(1):27-33.

40. Akasaka Y, Ueda H, Takayama K, Machida Y, Nagai T. Preparation and evaluation of bovine serum albumin nanospheres coated with monoclonal antibodies. Drug Des Deliv. 1988;3(1):85-97.
41. Kheirolomoom A, Lai CY, Tam SM, et al. Complete regression of local cancer using temperature-sensitive liposomes combined with ultrasoundmediated hyperthermia. J Control Release. 2013;172(1):266-273.

42. Zheng M, Yue C, Ma Y, et al. Single-step assembly of DOX/ICG loaded lipid-polymer nanoparticles for highly effective chemo-photothermal combination therapy. ACS Nano. 2013;7(3):2056-2067.

43. Mi Y, Guo Y, Feng SS. Nanomedicine for multimodality treatment of cancer. Nanomedicine (Lond). 2012;7(12):1791-1794.

44. Wang XY, Croswton JG, White AJ, et al. Interferon-alpha and interferongamma modulate Fas-mediated apoptosis in mitomycin-C-resistant human Tenon's fibroblasts. Clin Experiment Ophthalmol. 2014; 42(6):529-538

45. Xu B, He YF, Wu XH, Luo C, Liu A, Zhang J. Exploration of the correlations between interferon- $\gamma$ in patient serum and HEPACAM in bladder transitional cell carcinoma, and the interferon- $\gamma$ mechanism inhibiting BIU-87 proliferation. J Urol. 2012;188(4):1346-1353.

46. Park SY, Seol JW, Lee YJ, et a1. IFN-gamma enhance TRAIL induced apoptosis through IRF-1. Eur J Biochem. 2004;271(21):4222-4228.

47. Vaupel PW, Kelleher DK. Blood flow and associated pathophysiology of uterine cervix cancers: characterization and relevance for localised hyperthermia. Int J Hyperthermia. 2012;28(6):518-527.

48. Rao W, Deng ZS, Liu J. A review of hyperthermia combined with radiotherapy/chemotherapy on malignant tumors. Crit Rev Biomed Eng. 2010;38(1):101-116.
Drug Design, Development and Therapy

\section{Publish your work in this journal}

Drug Design, Development and Therapy is an international, peerreviewed open-access journal that spans the spectrum of drug design and development through to clinical applications. Clinical outcomes, patient safety, and programs for the development and effective, safe, and sustained use of medicines are a feature of the journal, which

\section{Dovepress}

has also been accepted for indexing on PubMed Central. The manuscript management system is completely online and includes a very quick and fair peer-review system, which is all easy to use. Visit http://www.dovepress.com/testimonials.php to read real quotes from published authors. 